\title{
Bad seed: the role of seed mass in dispersal and seedling success in the non-native, invasive perennial, Vincetoxicum rossicum.
}

\author{
A dissertation \\ submitted to the Faculty of Graduate Studies and Research \\ in partial fulfillment of the \\ requirements for the degree of \\ Master of Science \\ in Biology \\ by David Gerald Ladd \\ Carleton University \\ Ottawa, Ontario \\ January 2005 \\ (C) 2005, David Gerald Ladd
}




$\begin{array}{ll}\begin{array}{l}\text { Library and } \\ \text { Archives Canada }\end{array} & \begin{array}{l}\text { Bibliothèque et } \\ \text { Archives Canada }\end{array} \\ \begin{array}{l}\text { Published Heritage } \\ \text { Branch }\end{array} & \begin{array}{l}\text { Direction du } \\ \text { Patrimoine de l'édition }\end{array} \\ \begin{array}{l}\text { 395 Wellington Street } \\ \text { Ottawa ON K1A ON4 } \\ \text { Canada }\end{array} & \begin{array}{l}\text { 395, rue Wellington } \\ \text { Ottawa ON K1A ON4 } \\ \text { Canada }\end{array}\end{array}$

Your file Votre référence ISBN: 0-494-00782-6

Our file Notre référence

ISBN: 0-494-00782-6

NOTICE:

The author has granted a nonexclusive license allowing Library and Archives Canada to reproduce, publish, archive, preserve, conserve, communicate to the public by telecommunication or on the Internet, loan, distribute and sell theses worldwide, for commercial or noncommercial purposes, in microform, paper, electronic and/or any other formats.

The author retains copyright ownership and moral rights in this thesis. Neither the thesis nor substantial extracts from it may be printed or otherwise reproduced without the author's permission.
AVIS:

L'auteur a accordé une licence non exclusive permettant à la Bibliothèque et Archives Canada de reproduire, publier, archiver, sauvegarder, conserver, transmettre au public par télécommunication ou par l'Internet, prêter, distribuer et vendre des thèses partout dans le monde, à des fins commerciales ou autres, sur support microforme, papier, électronique et/ou autres formats.

L'auteur conserve la propriété du droit d'auteur et des droits moraux qui protège cette thèse. $\mathrm{Ni}$ la thèse ni des extraits substantiels de celle-ci ne doivent être imprimés ou autrement reproduits sans son autorisation.
In compliance with the Canadian

Privacy Act some supporting forms may have been removed from this thesis.

While these forms may be included in the document page count, their removal does not represent any loss of content from the thesis.
Conformément à la loi canadienne sur la protection de la vie privée, quelques formulaires secondaires ont été enlevés de cette thèse.

Bien que ces formulaires aient inclus dans la pagination, il n'y aura aucun contenu manquant. 


\begin{abstract}
Invasive plants pose a threat to local floras in many locations around the world. Invasion by non-native perennial vine Vincetoxicum rossicum (pale swallow-wort) in the northeastern United States and southern Ontario has recently attracted attention with its propensity to form monocultures in urban parklands. The goal of this study was to comprehensively assess whether seed mass affected the dispersal and subsequent success of seeds. Seed germination, seedling over-winter survivorship, and seedling presence in the second year were taken as measures of early colonization success. Increased seed mass predicted germination and subsequent seedling success. But seed mass did not predict decreased dispersal and because of this no evidence for a biological meaningful dispersal-establishment trade-off was found.
\end{abstract}




\section{Acknowledgements}

Thanks are as numerous and as widespread as seeds sent forth in the wind. To my supervisor, Dr. Naomi Cappuccino, for your continued belief in my capabilities despite my own doubts. Thanks to the other members of my committee, Dr. Lenore Fahrig and Dr. David Currie, you gave me advice when I asked, constructive criticisms when needed, \& compliments when I didn't even fish for them. Muchos thanks to Gerald and Matthew Ladd for mammoth help recording data in the field, countless hours building seed traps, and putting them into action. Thanks Mr. Curtis McKague for helping me weigh $>1000$ tiny seeds; gracias to him, Naomi, and Matt for seed planting efforts in '02. Honourable mentions to Heather Ladd, Neil Charbonneau, and Gail "my pup" Alivio for extra help in the field. Kisses, Baby-G. Thank-you for taking me on the St. John's Scademia boat tour with the Newfie dog even though you got sick $:$; To you, Kelly Cornell, and John Rauser, “476 Sunnyside forever!" Thanks, Mike Powell, Cynthia Roberts \& the Z-crew for zone recovery. Heartfelt thanks to the brekkie club for many years of coffee, grease, and good times: Moshi Kotierk, whose captivating stories, sincere friendship, OpenMike-Night stand-up, guerilla sleeping, and our 18 hour road trip to Red Rock (with sight-seeing!) I'll always cherish; Erik Klingbeil, who once fed me a cat treat and has forgotten more about Jeeps than I'll ever know; Glenn "portable" Murray, who drives a green goblin and made me sink the boat; Julie Slow, who just might be a Craker, likes to "Skor", and taught me to play "Killer Bunnies"; Carmen Gibbs, who is a sweet li'l thing, but embarrassingly won't let me have a drink; Donna Yee, the lively "Budgie Kwong"; Deb Quayle, who fondly remembers Captain Crank and the Buttery Man; Julie "Uber" Sircom, who taught me the true value of a local Starbucks and Edward Gorey postcards; 
Darryl Edwards, who taught me poker and how smooth Revelstoke is; Tonia Robb, who saw me get cut down by Dustin Diamond; and also Natasha Schokman, Marc Lajeunesse, and Dan McPhee. Thank-you's to members of the Landscape Ecology Lab: Tom Contreras, who got me keen on plants; Dave Omond, who fixed my balance; Neil, who is quick to laugh and forgive, I forgive your puns, if you forgive me "Crossroads"; Angela Darwin, the smartest cookie of all, who endured my leadership during icestorm fieldwork; Dan Bert who always had time to help (er...sacrifice) on any topic; to the statsqueens Julie Brennan, Julie Bouchard, and Rebecca Tittler, merci; Kringen Henein, who drew a picture of me; Max "Spider-max" Larivee, who is altogether the best guy (and superhero) you'd ever want to meet; Melissa Vance, WWMVD? fellow movie-lover, ulty coach for the Fresh Can of Whoop Ass, who looks like a ray of sunshine but has the most wicked, lightning-quick sense of humour of anyone I know and always tells it like it is, to your face, alas she's taken; by Moises Andrade who's perhaps even funnier; Jochen Jaeger, my favorite German and with whom I share memories of Algonquin Park canoe trips, campfire sing-a-longs, a sandy steak, and Swiss chocolates!; Rachelle McGregor, who swam with me in the Gulf at E.S.A. 2002 Savannah as part of our week-long buddy system, "dude!"; ever-popular Excedera St-Louis, Angela "but why?" Brommit, the evil Megan Whitehead, Stephanie "The Matrix" Duguay, and the nice Hume Douglas. Major kudos to Jeff Holland who can do or build anything (the real "Survivorman"), thanks for "kewl" tunes and organizing the Great Montreal Insect Road Trip (GMIRT), recall sugaring-off, and tiki-torch-lit night hockey, eh? I am proudly your friend. Most of all, thank-you to my sibs, Matt and Heather, and my parents Gerald and Janet for your love and support through all these years. To you my debt of gratitude is incalculable. 


\section{Table of Contents}

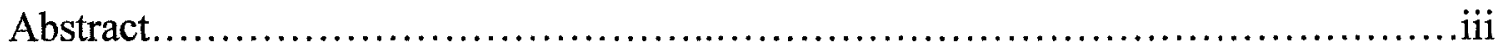

Acknowledgements............................................................

Table of Contents........................................................vii

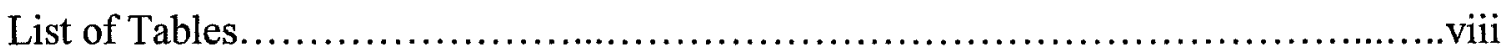

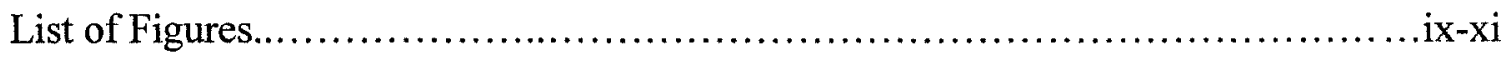

Chapter One - General Introduction........................................

1.1 Biological invasions................................................. 1

1.2 Vincetoxicum rossicum...............................................

1.3 Dispersal......................................................6

1.4 Germination.......................................................... 8

1.5 Combined studies................................................ 9

1.6 References..................................................... 11

Chapter Two - Germination, Survival, and Dispersal........................28

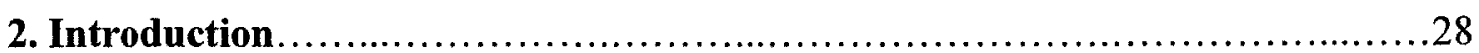

3. Materials and Methods.......................................................

3.1 Planting the germination garden..................................... 30

3.2 Seed germination and seedling success.............................. 31

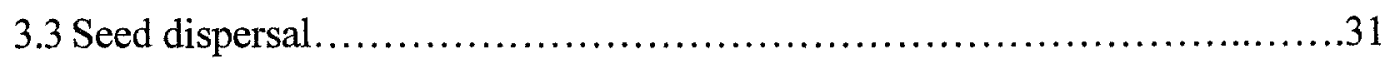

3.4 Germination statistical analyses......................................33

3.5 Survivorship statistical analyses................................... 34

3.6 Dispersal statistical analyses..................................... 35

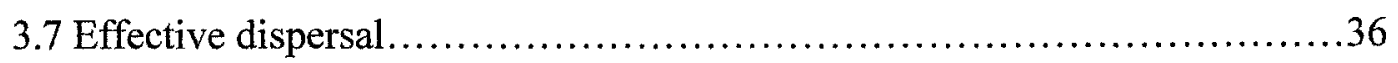

vi 


\section{Table of Contents (Continued)}

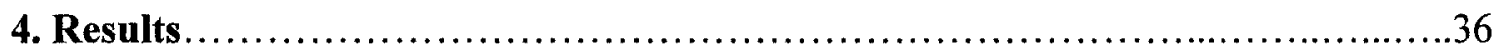

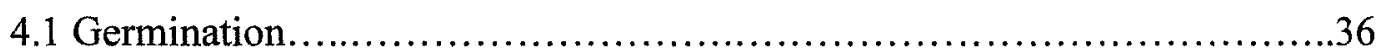

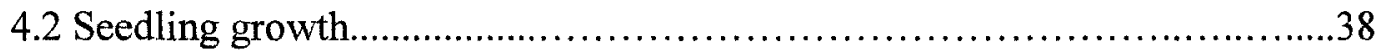

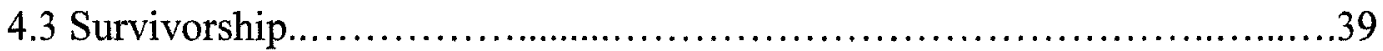

4.4 Dispersal.........................................................40

4.5 Effective dispersal...............................................4

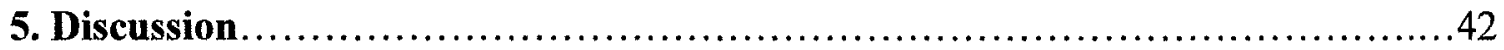

5.1 Germination....................................................... 42

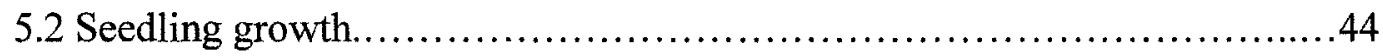

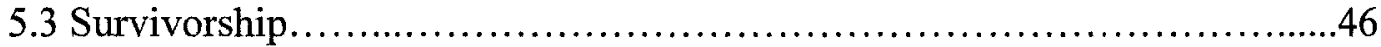

5.4 Dispersal.................................................... 46

5.5 Effective dispersal................................................49

5.6 Conclusions.............................................................. 52

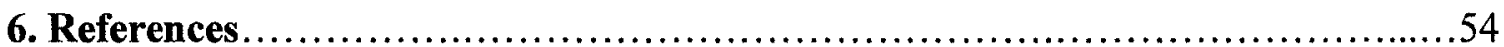

vii 


\section{List of Tables}

1. Results of logistic regression of the probability of $V$. rossicum germination on the independent variable seed mass in the above-ground and below-ground planting experiment .66

2. Seed mass (mg) of early and late germinating $V$. rossicum seeds in the above-ground and below-ground planting experiments.

3. Total heights $(\mathrm{cm})$ and leaf lengths $(\mathrm{mm})$ of early and late germinating $V$. rossicum seeds in the above-ground and below-ground planting experiments .66

4. Results of logistic regression of the probability of $V$. rossicum over-winter survivorship on the independent variables seed mass and total leaf length in the above-ground and below-ground planting experiments. 67

5. Likelihood-ratio chi-square tests of independence (G-tests) of $V$. rossicum over-winter survival versus early or late germination for the above-ground and below-ground planting experiments. .67

6. Results of logistic regressions of the probability of $V$. rossicum 2 nd year presence (2003) on the independent variable seed mass in the below-ground and above-ground planting experiments. .67

7. Spearman rank correlation for $V$. rossicum seed mass and dispersal distance including seeds trapped at $0 \mathrm{~m}$ from seed source plants .68

8. Spearman rank correlation for $V$. rossicum seed mass and dispersal distance excluding seeds trapped at $0 \mathrm{~m}$ from seed source plants 68

9. Spearman rank correlation for $V$. rossicum seed mass and dispersal distance excluding seeds trapped at $0 \mathrm{~m}$ from seed source plants

viii 


\section{List of Figures}

1. One of 16 transects in which each contains 15 seed traps placed at various distances for recording the dispersal of $V$. rossicum seeds in the fall of 2002.

2. $V$. rossicum seed mass in the above-ground and below-ground planting experiments. 70

3. Mean seed mass of $V$. rossicum first-time germinators in the above-ground experiment did not differ between the first season (2002) and the second season.... 70

4. Logistic regression of the probability of seed germination on seed mass in the first growing season for the above- and below-ground $V$. rossicum planting experiments..... 71

5. Percentage embryony status in the first season of germinated $V$. rossicum seeds in both planting experiments.........................................................

6. Mean seed mass of above-ground planted $V$. rossicum seeds with different numbers of germinated embryos

7. Mean seed masses of below-ground planted $V$. rossicum seeds with different numbers of germinated seedlings (season 1 ). 72

8. Maximum total height attained by $V$. rossicum seedlings from above-ground plantings in the first season predicted by seed mass. 73

9. Maximum total height attained by $V$. rossicum seedlings from below-ground plantings in the first season predicted by seed mass 73

10. Maximum total leaf length of $V$. rossicum seedlings in season 1 predicted by seed mass in the above-ground planting experiment 74

11. Maximum total leaf length of $V$. rossicum seedlings in season 1 predicted by seed mass in the below-ground planting experiment. 74

ix 


\section{List of Figures (Continued)}

12. $V$. rossicum seedling height and leaf length in season 1 were correlated in the above-

ground planting experiment. Pearson's r..................................... 75

13. $V$. rossicum seedling height and leaf length in season 1 were correlated in the belowground planting experiment. Pearson's r...................................... 75

14. Percentage over-winter survival of $V$. rossicum embryony classes in the above-ground planting experiment............................................................. 76

15. Percentage over-winter survival of $V$. rossicum embryony classes in the belowground planting experiment.................................................

16. Logistic regression of the probability of seedling presence in the second growing season on initial seed mass in $V$. rossicum above- and below-ground planting experi-

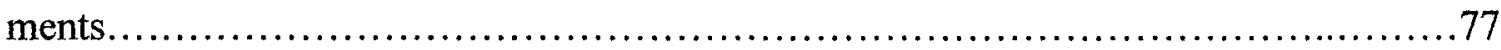

17. Numbers of filled and unfilled $V$. rossicum seeds dispersed to distances from source .78

18. Linear regression of arcsine transformed proportion unfilled $V$. rossicum seeds

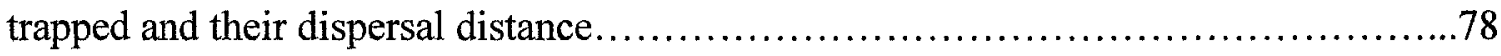
19. Linear regression of $V$. rossicum seed dispersal distance as a function of mass......79 20. Linear regression of $V$. rossicum dispersal beyond $0 \mathrm{~m}$ as a function of seed mass is not significant when two outliers removed....................................... 79 21. Estimated effective dispersal of $V$. rossicum or probability of germination at each distance. Values based on both planting experiments are shown .80 


\section{List of Figures (Continued)}

22. Estimated effective dispersal of $V$. rossicum or probability of seedling presence in the second season at each dispersal distance. Values based on both planting experiments are shown. 


\section{Chapter One: General Introduction}

\subsection{Biological Invasions}

Today, our global ecology is an invader's market. The worldwide mass transport of commerce and people both deliberately and accidentally moves species from their regions of origin to altogether new ones; the rate of novel species introductions with so little regard for geographic barriers is unprecedented (Vermeij 1991, D'Antonio \& Vitousek 1992, Lodge 1993, Vitousek et al. 1997a). Indeed, we may soon reach a point where none of our valued natural areas are unscathed from the assaults of exotic invasions (Usher 1988). The costs of invasion are not just aesthetic ones but economic as well; Pimentel (2000) estimated costs of damage by and control of exotic invasives in the United States is in excess of $\$ 130$ billion USD per year. The exigency of exotic invasions is that in many cases they are effectively irreversible (Coblentz 1990). Many contend that the serious threat posed to global biodiversity from biological invasions is second only to that of habitat loss (Vitousek et al. 1997b, Wilcove et al. 1998).

Alien invasive plants are well known to degrade habitat for native species (Brothers \& Spingarn 1992, Nee \& May 1992) and diminish native populations (Vitousek 1986, Randall 1996, Gordon 1998, Hobbs \& Mooney 1998). Change in ecosystem structure is wrought through decreases in native diversity, often from suppression of native seedling recruitment (Tyser 1992, Busch \& Smith 1995, Lesica \& Shelly 1996). When invasives take over, entire ecosystem processes can be affected (Melgoza et al. 1990, Verstraete \& Schwartz 1991, Walker \& Vitousek 1991); even biogeochemical and hydrological cycles can be changed (Vitousek et al. 1987, Ley \& D'Antonio 1998). 
Granted, many introduction attempts fail, and only a small percentage ultimately succeed, but the overall number of successes is still large (Pimentel et al. 1989, Mack et al. 2000). Williamson and Fitter (1996) devised a rule of tens such that one in ten introductions persist, one in ten persistent species proceeds to invade, and one in ten invaders becomes a pest problem. But these authors concede that variation in the data makes the one in ten rule anywhere between one in five to one in 20 ; the bottom line is that the exact probabilities are still not known.

Natural areas are increasingly under pressure from development including recreational use, trails, and dissection by roads and corridors. Human access leads to transportation of invaders to these areas and disturbance of the existing vegetation and soil structure; both these processes further facilitate invasion (Hobbs 1989, Noble 1989, Bergelson et al. 1993, Mack \& D'Antonio 1998, Schippers et al. 2001).

The underlying goals of research on invasive species have been to predict which species will invade and where invasions will occur. Some authors have attempted to identify life history traits that are common to successful invaders such as annual weeds (Perrins et al. 1992), birds in New Zealand and Australia (Newsome \& Noble 1986, Veltman et al. 1996), terrestrial plants (Noble 1989), and pasture plant species of North America (Lonsdale 1994)

It is probably not surprising that the two main characteristics for predicting invasiveness are previous invasiveness in other locations and a large native geographic range (Daehler \& Strong 1993). The first has been found for invading plants in Australia (Scott \& Panetta 1993), vertebrates (Ehrlich 1989), Hawaiian birds (Moulton \& Pimm 1986), and insects (Crawley 1987). A large native geographic range, perhaps 
indicative of wide environmental tolerances, has been linked to future success in a new range from analyses based on congeneric comparisons (Goodwin et al. 1999). Similarly, in herbaceous Poaceae, Asteraceae, and Fabaceae, invasiveness has been predicted from latitudinal range (Rejmánek 1996).

Models based on discriminant and regression analysis of life history and biogeographic characteristics have been used to develop predictive frameworks for woody invasives (Reichard \& Campbell 1996, Reichard \& Hamilton 1997, Reichard 1999). Life history traits associated with growth and reproduction have been used to predict invasiveness. High relative growth rate shortens the time to reproduction and increases the population growth rate; both of these factors increase the likelihood of population persistence after invasion (Baker 1965, 1974). Other traits such as small seed size, short juvenile period, and short interval between large seed crops have also been found to predict invasiveness in woody plants (Rejmánek 1996).

In efforts to find out where invasions succeed, authors have found that habitats with high disturbance and nutrient addition suffered the highest rates of invasion (Burke \& Grime 1996). Also, part of determining where invasions occur has included determining where they do not occur. An environment's resistance to invasion has been linked to its total species diversity (Naeem et al. 2000, Prieur-Richard et al. 2002).

\subsection{Vincetoxicum rossicum}

In eastern North America, amongst other places, swallow-worts are non-native, invasive, herbaceous perennial vines (Kirk 1985, Brown et al. 2001). Pale swallow-wort, Vincetoxicum rossicum (Kleo.) Barb., is native to the Ukraine and southeastern Russia 
(Markgraf 1972, McNeill 1981) and the distribution of the genus is for the most part temperate (Liede 1996). The nomenclature of the genus in North America has been controversial and confusing (Bullock 1958, Ross 1966, 1967, Markgraf 1972, Liede 1996); the main synonym still in use is Cynanchum rossicum (USDA NRCS 2004). The history of the invasion of Vincetoxicum rossicum and its close relative V. nigrum in eastern North America has been described (Sheeley 1992, Sheeley \& Raynal 1996); the genus has been present in Ontario for almost a century (Macoun 1906, Pringle 1973). In both Canada and the United States, the risk of spread of the two species was recognized decades ago (Monachino 1957, Moore 1959). Within the past few decades, the visibility of the plant as a serious pest has increased (Pringle 1973, Kaiser 1986, Riley 1989, Christensen 1998, Webster 2003). The distribution of $V$. rossicum in southern Ontario has been described and mapped (Pringle 1973, Kirk 1985), although occurrences have also been reported for Quebec and possibly British Columbia as well (Moore 1959, Scoggan 1979). The general consensus has been that the range of Vincetoxicum sp. is expanding westward (Moore 1959, Pringle 1973, Sheeley 1992,Sheeley \& Raynal 1996).

Vincetoxicum rossicum has been reported as being more successful in sunny or open sites (Sheeley 1992, Christensen 1998); these types of areas are often characteristic habitat of urban parks (Webster 2003). Dog-strangling vine can grow to lengths of 2 to 3 $m$ during a single season and can reach such a height if the support of woody vegetation is present such as in forest edges or fencerows. In large stands, $V$. rossicum plants will twine around each other and fall over under their own weight forming large mats of tangled vines. 
The root system is well developed into a dense structure that could be described as a root ball. This structure may allow the plant to survive times of stress including drought and soil disturbance. Clonal growth from rhizomes has been observed in $V$. nigrum (Lumer \& Yost 1995) but not in V. rossicum (Sheeley 1992, Sheeley \& Raynal 1996, Christensen 1998, Lawlor 2000). However, the ability to resprout from perennating buds located at the top of the root crown still presents the greatest obstacle for manual removal efforts (Lawlor \& Raynal 2002).

The flowers of pale swallow-wort are arranged in fascicles and found on peduncles that measure $2-5 \mathrm{~cm}$ long and arise from the axils of the leaves (Moore 1959). The flowers are small, 5-point star corollas $5-10 \mathrm{~mm}$ wide and coloured pale purple to maroon. The corolla lobes are lanceolate and smooth with a length approximately twice their width $(2 \mathrm{~mm} \times 4-5 \mathrm{~mm})$ (Moore 1959). Flowering of Vincetoxicum in Ottawa occurs from June to August. Floral visitors that have been reported elsewhere include such general nectar gatherers as flies, bees, wasps, ants, and beetles (Lumer \& Yost 1995, Christensen 1998, Lawlor 2000).

Fertilization by autogamy is possible in V. rossicum (St.Denis \& Cappuccino 2004) and in its close relative V. nigrum (Lumer \& Yost 1995). The seeds are carried in pods, $4-8 \mathrm{~cm}$ long, that are often paired to resemble a swallow's tail, thus lending the common name (Lawlor 2002). The plants turn yellow late in the season when early maturing fruits in the Ottawa region release seeds in early September, while later maturing fruits release seeds well into November from the dehiscent pods (Cappuccino et al. 2002). 
Like many members of the family Asclepiadaceae, V. rossicum possesses comose, wind-dispersed seeds, which are very similar in appearance to those of common milkweed (Asclepias syriaca). The seeds are lighter than those of $A$. syriaca, which itself has been considered a good disperser (Platt 1975, Wilbur 1976, Platt \& Weis 1977, 1977). V. rossicum seeds are not as flattened as those of $A$. syriaca and the coma is not as long or as large.

$V$. rossicum also differs from $A$. syriaca by its capacity for polyembryony in some of its seeds (Sheeley 1992). Work by Hausner (1976) has characterized polyembryony in $V$. rossicum, including rates of occurrence in terms of numbers of embryos. Rates of polyembryony among germinated seedlings have also been reported by Cappuccino et al. (2002).

In general, little is known about the germination of $V$. rossicum and nothing about its early growth and survivorship, which ultimately leads to establishment and a mature plant. Seed release dispersal distances in the field have been reported by Cappuccino $e t$ al. (2002). These authors also recorded germination and seedling growth under greenhouse conditions both with and without competition.

\subsection{Dispersal}

The study of shape, form and structure of seeds has shown inherent differences between modes of dispersal and between species (Ridley 1930). Various modes of dispersal can also operate in conjunction (Westoby \& Rice 1981, Clifford \& Monteith 1989, Stamp \& Lucas 1990) or in stages (Watkinson 1978, Liddle \& Elgar 1984, 
Chambers \& MacMahon 1994). Wind-dispersed species are usually aided by accessory structures such as wings or plumes (Burrows 1973, 1975a, 1975b, Augspurger 1986).

Primary dispersal occurs when the seed initially leaves the maternal plant until the seed lands on the ground. Secondary dispersal comprises any movement after this point usually on or near the ground (Johnson \& Fryer 1992), especially over a snow layer or extremely open landscape (Lacey 1982, Matlack 1989, Feldman \& Lewis 1990, Fort \& Richards 1998). The range of secondary movement can be affected by slope aspect, vegetation structure, surface roughness, and wind speed and direction (Mortimer 1974, Watkinson 1978, Johnson \& West 1988, 1992).

Dispersal allows colonization of new sites, which influences population dynamics and comprises an important component of conservation and restoration strategies for plants at risk (Strykstra et al. 1998a, Zobel et al. 1998, Bakker \& Berendse 1999, Gravuer et al. 2003). Conversely, the rates of invasion of undesirable species are constrained by dispersal and long-distance dispersal may lead to new points of invasion. Many have asserted that long-distance dispersal holds disproportionate importance on a long-term or evolutionary time scale for numerous processes: Holocene plant migrations (Davis 1987, Cain et al. 1998, Clark 1998), rates of change in species distributions under future climate change (Dyer 1995, Iverson \& Prasad 1998, Hansen \& Dale 2001, Hansen et al. 2001), rates of invasion (Clark et al. 2003), and aliens reaching new focal points for establishment (Moody \& Mack 1988). The importance of dispersal to invasions is such that the recommendation has repeatedly been made for dispersal potential be a requisite part of plant invasion risk assessments (Poschlod et al. 1996, Ehrlén \& van Groenendael 1998, Menges 2000). 
From early on, it has been recognized that rare, nonstandard means of dispersal (Darwin 1859, Higgins et al. 2003) and extreme meteorological events (Webber 1934) could drastically change the outcome of individual dispersal events; for example, wind updrafts could potentially transport seeds very far (Ridley 1906, 1930). More recently, seed size has been considered an important quantity. Small seeds that are wind-dispersed are always expected to disperse farther than large seeds.

\subsection{Germination}

The success of plant dispersal is ultimately determined by germination of the dispersed propagule. Seeds vary in size both inter- and intraspecifically. Seed size has repeatedly been found to positively influence germination rates. The benefits accrued from large seed size and particularly from seed mass for early seedling success are well established and wide-ranging. Larger seeds better provision the embryo (Venable \& Brown 1988); larger seedlings are produced from larger seeds (Wulff 1986, Stanton 1984, Black 1958, Abul-Fatih \& Bazzazz 1979, Howe \& Richter 1982, Gonzalez 1993) with few exceptions (Carelton \& Cooper 1972). Greater seed size confers tolerance of an array of hazards including resistance to damage of the seed itself (Dalling et al. 1997) and to the cotyledons (Kitajima 1996, Armstrong \& Westoby 1993, Bonfil 1998). Large seed size also protects the seedling against initial nutrient limitation (Jurado \& Westoby 1992, Seiwa 2000) and shaded conditions (Saverimuttu \& Westoby 1996, Leishman \& Westoby 1994, Osunkoya et al. 1994, Hewitt 1998, Bond et al. 1999, Paz \& Martínez-Ramos

2003). Whether germination occurs early or late primarily will depend on seeds' 
enteroceptive sense of their environment. However, early germination may be more like to occur with heavier seeds in some species (e.g. Simons and Johnston 2000).

In most dispersal systems, most or nearly all seeds fall directly underneath maternal plant canopies (Levin \& Kerster 1974, Harper 1977, Howe \& Smallwood 1982). Extremely dense concentrations of siblings close to the parents severely curtail chances of seedling survivorship due to competition, predation, and pathogens (Augspurger 1983, Janzen 1970, Connell 1971, Platt 1976, Clark \& Clark 1984, Becker \& Wong 1985, Howe et al. 1985, Wills et al. 1997, Harms et al. 2000)

\subsection{Combination Studies}

Dispersal and germination processes and their relation to seed mass have usually been studied as separate issues in ecology. Much more rarely has research been performed that examined the two in concert, although it has been advocated repeatedly (Ribbens et al. 1994, Houle 1995, Schupp \& Fuentes 1995).

Some studies of the effect of seed mass on dispersal and germination have measured dispersal in the laboratory and germination in a similarly controlled environment. Meyer and Carlson (2001) found that falling speed in still air was only weakly related to mass. In their growth chamber experiment seedling survivorship at 2 and 4 weeks was unrelated to seed mass. However, at 2 weeks, seed mass was positively related to seedling weight. Strykstra et al. (1998b) measured dispersal distance in a wind tunnel and seed mass. They observed a negative relationship between dispersal distance and the subsequent germination rate of seeds in petri dishes. Gravuer et al. (2003) parameterized dispersal by performing drop time and wind tunnel experiments on a 
subset of seeds for which individual dimensional measurements were also made. The drop time measurement and the distance travelled in the wind tunnel were their estimates of dispersal ability. The same seeds were then planted in the greenhouse. Both dispersal estimates were found to be highly significantly and negatively related to germination success.

Some studies have tested dispersal in the field and germination in the greenhouse or growth chamber to gain information about colonization ability. Colbach and Sache (2001) found that germinated seeds were heavier but in their dispersal experiment, they found no relation between seed weight and distance. Stergios (1976) found a direct negative relationship between dispersal distance in the field and germination percentage in the laboratory of Hieracium aurantiacum, but he atypically used seed volume instead of seed mass. He reported a negative relationship between seed volume and dispersal distance but did not report information relating seed volume to germination percentage. Over-winter survivorship could not be evaluated with respect to distance due to near 100\% mortality. Cappuccino et al. (2002) found a significant negative relationship between seed weight and dispersal distance and a significant positive relationship between seed weight and germination for $V$. rossicum that was in competition with grasses in the greenhouse.

Fewer authors have used field experiments for both the dispersal and germination components for such a study. Morse and Schmitt (1985) measured both seed dispersal distance of common milkweed (Asclepias syriaca) in the field and falling time in the lab, but seed mass was only negatively related to the lab measure of dispersal. Morse and Schmitt also found that germination was negatively related only to the dispersal ability in 
the lab. First season seedling survivorship and biomass was unrelated to either dispersal measure. Debain et al. (2003) found no significant relationship between terminal velocity and seedling growth in Pinus sylvestris. Neither did they find a relationship between seed mass and seedling survival at 6 months.

\subsection{References}

Abul-Fatih, H.A., and F.A. Bazzazz. 1979. The biology of Ambrosia trifida L. II. Germination, emergence, growth, and survival. New Phytologist 83: 817-827.

Armstrong, D.P., and M. Westoby. 1993. Seedlings from large seeds tolerate defoliation better: a test using phylogenetically independent contrasts. Ecology 74: 10921100.

Augspurger, C.K. 1983. Seed dispersal of the tropical tree, Platypodium elegans, and the escape of its seedlings from fungal pathogens. Journal of Ecology 71: 759-771.

Augspurger, C.K. 1986. Morphology and dispersal potential of wind-dispersed diaspores of neotropical trees. American Journal of Botany 73: 353-363.

Baker, H.G. 1965. Characteristics and modes of origin of weeds. Pages 147-168 in H.G. Baker, and G.L. Stebbins, editors. The genetics of colonizing species. Academic, New York.

Baker, H.G. 1974. The evolution of weeds. Annual Review of Ecology and Systematics 5: $1-24$.

Bakker, J.P., and F. Berendse. 1999. Constraints in the restoration of ecological diversity in grassland and heathland communities. Trends in Ecology \& Evolution 14: 6368. 
Becker, P., and M. Wong. 1985. Seed dispersal, seed predation, and juvenile mortality of Aglaia sp. (Meliaceae) in lowland dipterocarp rainforest. Biotropica 17: 230-237.

Bergelson, J., J.A. Newman, and E.M. Floresroux. 1993. Rates of weed spread in spatially heterogeneous environments. Ecology 74: 999-1011.

Black, J.N. 1958. Competition between plants of different initial seed sizes in swards of subterranean clover (T. subterraneum $\mathrm{L}$.) with particular reference to leaf area and light microclimate. Australian Journal of Agricultural Research 9: 299-318.

Bond, W.J., M. Honig, and K.E. Maze. 1999. Seed size and seedling emergence: an allometric relationship and some ecological implications. Oecologia 120: 132136.

Bonfil, C. 1998. The effects of seed size, cotyledon reserves, and herbivory on seedling survival and growth in Quercus rugosa and Q. laurina (Fagaceae). American Journal of Botany 85: 79-87.

Brothers, T.S., and A. Spingarn. 1992. Forest fragmentation and alien plant invasion of central Indiana old-growth forests. Conservation Biology 6: 91-100.

Brown, W.T., M.E. Krasny, and N. Schoch. 2001. Volunteer monitoring of nonindigenous invasive plant species in the Adirondack Park, New York, USA. Natural Areas Journal 21: 189-196.

Bullock, A.A. 1958. Nomenclatural notes: X. On the application of the name Vincetoxicum. Kew Bulletin 13: 302.

Bullock, A.A. 1967. Nomenclatural notes: XVII. Vincetoxicum again! Kew Bulletin 21: 351-352.

Burke, M.J.W., and J.P. Grime. 1996. An experimental study of plant community invasibility. Ecology 77: 776-790. 
Burrows, F.M. 1975a. Calculation of primary trajectories of dust seeds, spores and pollen in unsteady winds. New Phytologist 75: 389-403.

Burrows, F.M. 1975b. Wind-borne seed and fruit movement. New Phytologist 75: 405418.

Burrows, F.M. 1973. Calculation of primary trajectories of plumed seeds in steady winds with variable convection. New Phytologist 72: 647-664.

Busch, D.E., and S.D. Smith. 1995. Mechanisms associated with decline of woody species in riparian ecosystems of the southwestern U.S. Ecological Monographs 65: $347-370$.

Cain, M.L., H. Damman, and A. Muir. 1998. Seed dispersal and the holocene migration of woodland herbs. Ecological Monographs 68: 325-347.

Cappuccino, N., R. Mackay, and C. Eisner. 2002. Spread of the invasive alien vine Vincetoxicum rossicum: tradeoffs between seed dispersability and seed quality. American Midland Naturalist 148: 263-270.

Carelton, A.E., and C.S. Cooper. 1972. Seed size effects upon seedling vigor of three forage legumes. Crop Science 12: 183-186.

Chambers, J.C., and J.A. MacMahon. 1994. A day in the life of a seed: movements and fates of seeds and their implications for natural and managed systems. Annual Review of Ecology and Systematics 25: 263-292.

Christensen, T. 1998. Swallowworts: the ecology and control of Vincetoxicum spp. Wildflower Summer: 21-25.

Clark, D.A., and D.B. Clark. 1984. Spacing dynamics of a tropical rain forest tree: evaluation of the Janzen-Connell model. American Naturalist 124: 769-788. 
Clark, J.S. 1998. Why trees migrate so fast: confronting theory with dispersal biology and the paleorecord. American Naturalist 152: 204-224.

Clark, J.S., M. Lewis, J.S. McLachlan, and J. HilleRisLambers. 2003. Estimating population spread: what can we forecast and how well? Ecology 84: 1979-1988.

Clifford, H.T., and G.B. Monteith. 1989. A three phase seed dispersal mechanism in Australian quinine bush (Petalostigma pubescens Domin.). Biotropica 21: 284286.

Coblentz, B.E. 1990. Exotic organisms: a dilemma for conservation biology. Conservation Biology 4: 261-265.

Colbach, N., and I. Sache. 2001. Blackgrass (Alopecurus myosuroides Huds.) seed dispersal from a single plant and its consequences on weed infestation. Ecological Modelling 139: $201-219$.

Connell, J.H. 1971. On the role of natural enemies in preventing competitive exclusion in some marine animals and in rain forest trees. Pages 298-312 in P. J. Den Boer, and G. Gradwell, editors. Dynamics of populations. PUDOC Scientific Publications, Wageningen, Netherlands.

Crawley, M.J. 1987. What makes a community invasible? Pages 429-453 in A.J. Gray, M.J. Crawley, and P.J. Edwards, editors. Colonization, succession and stability. Blackwell Scientific Publications, Oxford.

D'Antonio, C.M., and P.M. Vitousek. 1992. Biological invasion by exotic grasses, the grass/fire cycle and global change. Annual Review of Ecology and Systematics 23: $63-87$.

Daehler, C.C., and D.R. Strong. 1993. Prediction and biological invasions. Trends in Ecology \& Evolution 8: 380. 
Dalling, J.W., K.E. Harms, and R. Aizprua. 1997. Seed damage tolerance and seedling resprouting ability of Prioria copaifera in Panama. Journal of Tropical Ecology 13: $481-490$.

Darwin C. 1859. On the origin of species by means of natural selection. John Murray, London, UK.

Davis, M.B. 1987. Invasions of forest communities during the Holocene: beech and hemlock in the Great Lakes region. Pages 373-393 in A.J. Gray, M.J. Crawley, and P.J. Edwards, editors. Colonization, succession and stability. Blackwell Scientific Publications, Oxford.

Debain, S., T. Curt, and J. Lepart. 2003. Seed mass, seed dispersal capacity, and seedling performance in a Pinus sylvestris population. Ecoscience 10: 168-175.

Dyer, J.M. 1995. Assessment of climatic warming using a model of forest species migration. Ecological Modelling 79: 199-219.

Ehrlén, J., and J. van Groenendael. 1998. The trade-off between dispersability and longevity: an important aspect of plant species diversity. Applied Vegetation Science 1: 29-36.

Ehrlich, P.R. 1989. Attributes of invaders and the invading process: vertebrates. Pages 315-328 in J.A. Drake, H.A. Mooney, F. di Castri, R.H. Groves, F.J. Kruger, M. Rejmánek, and M. Williamson, editors. Biological invasions, a global perspective. John Wiley and Sons, London, UK.

Feldman, S.R., and J.P. Lewis. 1990. Output and dispersal of propagules of Carduus acanthoides L. Weed Research 30: 161-169.

Fort, K.P., and J.H. Richards. 1998. Does seed dispersal limit initiation of primary succession in desert playas? American Journal of Botany 85: 1722-1731. 
Gonzalez, E. 1993. Effect of seed size on germination and seedling vigor of Virola koschnyi Warb. Forest Ecology and Management 57: 275-281.

Goodwin, B.J., A.J. McAllister, and L. Fahrig. 1999. Predicting invasiveness of plant species based on biological information. Conservation Biology 13: 422-426.

Gordon, D.R. 1998. Effects of invasive, non-indigenous plant species on ecosystem processes: lessons from Florida. Ecological Applications 8: 975-989.

Gravuer, K., E.J. Von Wettberg, and J. Schmitt. 2003. Dispersal biology of Liatris scariosa var. novae-angliae (Asteraceae), a rare New England grassland perennial. American Journal of Botany 90: 1159-1167.

Hansen, A., and V. Dale. 2001. Biodiversity in US Forests under global climate change. Ecosystems 4: 161-163.

Hansen, A.J., R.P. Neilson, V.H. Dale, C.H. Flather, L.R. Iveson, D.J. Currie, S. Shafer, R. Cook, and P.J. Bartlein. 2001. Global change in forests: responses of species, communities, and biomes. BioScience 51: 765-779.

Harms, K.E., S.J. Wright, O. Calderon, A. Hernandez, and E.A. Herre. 2000. Pervasive density-dependent recruitment enhances seedling diversity in a tropical forest. Nature 404: 493-495.

Harper J.L. 1977. Population biology of plants. Academic Press, New York.

Hausner, G.v. 1976. Embryogenese and nucellar-polyembryonie bei CynanchumVincetoxicum-Arten. Beitraege zur Biologie der Pflanzen 52: 101-126.

Hewitt, N. 1998. Seed size and shade-tolerance: a comparative analysis of North American temperate trees. Oecologia 114: 432-440.

Higgins, S.I., R. Nathan, and M.L. Cain. 2003. Are long-distance dispersal events in plants usually caused by nonstandard means of dispersal? Ecology 84: 1945-1956. 
Hobbs, R.J. 1989. The nature and effects of disturbance relative to invasions. Pages 389405 in J.A. Drake, H.A. Mooney, F. di Castri, R.H. Groves, F.J. Kruger, M. Rejmánek, and M. Williamson, editors. Biological invasions: a global perspective. Wiley, Chichester, UK.

Hobbs, R.J., and H.A. Mooney. 1998. Broadening the extinction debate: population deletions and additions in California and Western Australia. Conservation Biology 12: 271-283.

Houle, G. 1995. Seed dispersal and seedling recruitment: the missing link(s). Ecoscience 2: $238-244$.

Howe, H.F., and W.M. Richter. 1982. Effects of seed size on seedling size in Virola surinamensis: a within and between tree analysis. Oecologia 53: 347-351.

Howe, H.F., E.W. Schupp, and L.C. Westley. 1985. Early consequences of seed dispersal for a neotropical tree (Virola surinamensis). Ecology 66: 781-791.

Howe, H.F., and J. Smallwood. 1982. Ecology of seed dispersal. Annual Review of Ecology and Systematics 13: 201-228.

Iverson, L.R., and A.M. Prasad. 1998. Predicting abundance of 80 tree species following climate change in the eastern United States. Ecological Monographs 68: 465-485.

Janzen, D.H. 1970. Herbivores and number of tree species in tropical forests. American Naturalist 104: 501-528.

Johnson, C.K., and N.E. West. 1988. Laboratory comparisons of 5 seed-trap designs for dry, windy environments. Canadian Journal of Botany 66: 346-348.

Johnson, E.A., and G.I. Fryer. 1992. Physical characterization of seed microsites: movement on the ground. Journal of Ecology 80: 823-836. 
Jurado, E., and M. Westoby. 1992. Seedling growth in relation to seed size among species of arid Australia. Journal of Ecology 80: 407-416.

Kaiser, J. 1986. Exotic species of plants that are potential weeds of natural areas. in Proceedings of the Annual Meeting of the Ontario Chapter, Canadian Land Reclamation Association, May 5, 1986. Jordan Harbour, Ontario.

Kirk, M. 1985. Vincetoxicum spp. (dog-strangling vines): alien invaders of natural ecosystems in Southern Ontario. Plant Press 3: 130-131.

Kitajima, K. 1996. Cotyledon functional morphology, seed reserve utilization, and regeneration niches of tropical tree seedlings. Pages 193-208 in M. D. Swaine, editor. The ecology of tropical forest seedlings. UNESCO, Paris.

Lacey, E.P. 1982. Timing of seed dispersal in Daucus carota. Oikos 39: 83-91.

Lawlor, F.M. 2000. Herbicidal treatment of the invasive plant Cynanchum rossicum and experimental post control restoration of infested sites. State University of New York College of Environmental Science and Forestry. M.Sc. Thesis.

Lawlor F.M. 2002. Element stewardship abstract for Vincetoxicum nigrum (L.) Moench. and Vincetoxicum rossicum (Kleopov) Barbarich - swallow-wort. Prepared for The Nature Conservancy and available online. Pages 1-13. M. Tu, and J.M. Randall, editors. The Nature Conservancy. 4-5-2004. URL: http://ncweeds.ucdavis.edu/esadocs/documnts/vinc_sp.pdf Accessed. 7-4-2004.

Lawlor, F.M., and D.J. Raynal. 2002. Response of swallow-wort to herbicides. Weed Science 50: $179-185$.

Leishman, M.R., and M. Westoby. 1994. The role of large seed size in shaded conditions: experimental evidence. Functional Ecology 8: 205-214. 
Lesica, P., and J.S. Shelly. 1996. Competitive effects of Centaurea maculosa on the population dynamics of Arabis fecunda. Bulletin of the Torrey Botanical Club 123: 111-121.

Levin, D.A., and H.W. Kerster. 1974. Gene flow in seed plants. Pages 139-220 in T. Dobzhansky, M.K. Hecht, and W.C. Steere, editors. Evolutionary Biology [7], New York, Plenum Press.

Ley, R.E., and C.M. D'Antonio. 1998. Exotic grass invasion alters potential rates of $\mathrm{N}$ fixation in Hawaiian woodlands. Oecologia 113: 179-187.

Liddle, M.J., and M.A. Elgar. 1984. Multiple pathways in diaspore dispersal, exemplified by studies of noogoora burr (Xanthium occidentale Bertol., Compositae). Botanical Journal of the Linnean Society 88: 303-315.

Liede, S. 1996. Cynanchum, Rhodostegiella, Vincetoxicum, Tylophora (Asclepiadaceae): new considerations on an old problem. Taxon 45: 193-211.

Lodge, D.M. 1993. Biological invasions: lessons for ecology. Trends in Ecology \& Evolution 8: 133-137.

Lonsdale, W.M. 1994. Inviting trouble: introduced pasture species in northern Australia. Australian Journal of Ecology 19: 345-354.

Lumer, C., and S.E. Yost. 1995. The reproductive biology of Vincetoxicum nigrum (L.) Moench. (Asclepiadaceae), a Mediterranean weed in New York State. Bulletin of the Torrey Botanical Club 122: 15-23.

Mack, M.C., and C.M. D'Antonio. 1998. Impacts of biological invasions on disturbance regimes. Trends in Ecology \& Evolution 13: 195-198.

Mack, R.N., D. Simberloff, W.M. Lonsdale, H. Evans, M. Clout, and F.A. Bazzaz. 2000. Biotic invasions: causes, epidemiology, global consequences, and control. Ecological Applications 10: 689-710. 
Macoun, J.M. 1906. Contributions to Canadian botany. XVII. Ottawa Naturalist 20: 162172.

Markgraf, F. 1972. Vincetoxicum N.M. Wolf. Pages 70-73 in T.G. Tutin, V.H. Heywood, N.A. Burges, D.M. Moore, D.H. Valentine, S.M. Walters, and D.A. Webb, editors. Flora Europaea. Cambridge University Press, Cambridge, UK.

Matlack, G.R. 1989. Secondary dispersal of seed across snow in Betula lenta, a gapcolonizing tree species. Journal of Ecology 77: 853-869.

McNeill, J. 1981. Taxonomic, nomenclatural and distributional notes on Canadian weeds and aliens. Naturaliste Canadien 108: 237-244.

Melgoza, G., R.S. Nowak, and R.J. Tausch. 1990. Soil water exploitation after fire: competition between Bromus tectorum (cheatgrass) and two native species. Oecologia 83: 7-13.

Menges, E.S. 2000. Population viability analyses in plants: challenges and opportunities. Trends in Ecology \& Evolution 15: 51-56.

Meyer, S.E., and S.L. Carlson. 2001. Achene mass variation in Ericameria nauseosus (Asteraceae) in relation to dispersal ability and seedling fitness. Functional Ecology 15: 274-281.

Monachino, J. 1957. Cynanchum in the New York area. Bulletin of the Torrey Botanical Club 84: 47-58.

Moody, M.E., and R.N. Mack. 1988. Controlling the spread of plant invasions: the importance of nascent foci. Journal of Applied Ecology 25: 1009-1021.

Moore, R.J. 1959. The dog-strangling vine Cyanchum medium its chromosome number and its occurrence in Canada. The Canadian Field-Naturalist 73: 144-147. 
Morse, D.H., and J. Schmitt. 1985. Propagule size, dispersal ability, and seedling performance in Asclepias syriaca. Oecologia 67: 372-379.

Mortimer, A.M. 1974. Studies of germination and establishment of selected species with special reference to the fates of seeds. University College of Wales.

Moulton, M.P., and S.L. Pimm. 1986. Species introduction to Hawaii. Pages 231-249 in H.A. Mooney, and J.A. Drake, editors. Ecological Studies [58], New York, Springer.

Naeem, S., J.M.H. Knops, D. Tilman, K.M. Howe, T. Kennedy, and S. Gale. 2000. Plant diversity increases resistance to invasion in the absence of covarying extrinsic factors. Oikos 91: 97-108.

Nee, S., and R.M. May. 1992. Dynamics of metapopulations: habitat destruction and competitive coexistence. Journal of Animal Ecology 61: 37-40.

Newsome, A.E., and I.R. Noble. 1986. Ecological and physiological characters of invading species. Pages 1-20 in R.H. Groves, and J.J. Burdon, editors. Ecology of biological invasions. Cambridge University Press, Cambridge, UK.

Noble, I.R. 1989. Attributes of invaders and the invading process: terrestrial and vascular plants. Pages 301-313 in J.A. Drake, H.A. Mooney, F. di Castri, R.H. Groves, F.J. Kruger, M. Rejmánek, and M.H. Williamson, editors. Biological invasions: a global perspective. Wiley, Chichester, UK.

Osunkoya, O.O., J.E. Ash, M.S. Hopkins, and A.W. Graham. 1994. Influence of seed size and seedling ecological attributes on shade-tolerance of rain-forest tree species in Northern Queensland. Journal of Ecology 82: 149-163.

Paz, H., and M. Martínez-Ramos. 2003. Seed mass and seedling performance within eight species of Psychotria (Rubiaceae). Ecology 84: 439-450. 
Perrins, J., M. Williamson, and A. Fitter. 1992. Do annual weeds have predictable characters? Acta Oecologia 13: 517-533.

Pimentel, D., M.S. Hunter, J.A. LaGro, R.A. Efroymson, J.C. Landers, F.T. Mervis, C.A. McCarthy, and A.E. Boyd. 1989. Benefits and risks of genetic engineering in agriculture. Socioeconomic and environmental problems may be associated with transfer of traits. BioScience 39: 606-614.

Pimentel, D., L. Lach, R. Zuniga, and D. Morrison. 2000. Environmental and economic costs of nonindigenous species in the United States. BioScience 50: 53-64.

Platt, W.J. 1975. Colonization and formation of equilibrium plant species associations on badger disturbances in a tall grass prairie. Ecological Monographs 45: 285-305.

Platt, W.J. 1976. Natural history of a fugitive prairie plant (Mirabilis hirsuta (Pursh.) Macm.). Oecologia 22: 399-409.

Platt, W.J., and I.M. Weis. 1977. Resource partitioning and competition within a guild of fugitive prairie plants. American Naturalist 111: 479-513.

Poschlod, P., J. Bakker, S. Bonn, and S. Fischer. 1996. Dispersal of plants in fragmented landscapes. Pages 123-127 in J. Settele, C.R. Margules, P. Poschlod, and K. Henle, editors. Species survival in fragmented landscapes. Kluwer Academic Publishers, Dordrecht, The Netherlands.

Prieur-Richard, A.-H., S. Lavorel, Y.B. Linhart, and A. Dos Santos. 2002. Plant diversity, herbivory and resistance of a plant community to invasion in Mediterranean annual communities. Oecologia 130: 96-104.

Pringle, J.S. 1973. The spread of Vincetoxicum species (Asclepiadaceae) in Ontario. The Canadian Field-Naturalist 87: 27-33.

Randall, J.M. 1996. Weed control for the preservation of biological diversity. Weed Technology 10: 370-383. 
Reichard, S.H. 1999. A method for evaluating plant invasiveness. Public Garden 14(2): $19-21$.

Reichard, S.H., and F. Campbell. 1996. Invited but unwanted. American Nurseryman 184: $39-45$.

Reichard, S.H., and C.W. Hamilton. 1997. Predicting invasion of woody plants introduced into North America. Conservation Biology 11: 193-203.

Rejmánek, M. 1996. A theory of seed plant invasiveness: the first sketch. Biological Conservation 78: 171-181.

Ribbens, E., J.J. Silander, and S.W. Pacala. 1994. Seedling recruitment in forests: calibrating models to predict patterns of tree seedling dispersion. Ecology 75: 1794-1806.

Ridley, H.N. 1906. On the dispersal of seeds by wind. Annals of Botany 19: 351-363.

Ridley, H.N. 1930. The dispersal of plants throughout the world. Reeve, Ashford, UK.

Riley, J.L. 1989. More invasive aliens. Seasons 29: 23.

Ross, R. 1966. The generic names published by N.M. Von Wolf. Acta Botanica Neerlandica 15: 147-161.

Saverimuttu, T., and M. Westoby. 1996. Components of variation in seedling potential relative growth rate: phylogenetically independent contrasts. Oecologia 105: 281285.

Schippers, P., J.M. van Groenendael, L.M. Vleeshouwers, and R. Hunt. 2001. Herbaceous plant strategies in disturbed habitats. Oikos 95: 198-210. 
Schupp, E.W., and M. Fuentes. 1995. Spatial patterns of seed dispersal and the unification of plant population ecology. Ecoscience 2: 267-275.

Scoggan, H.J. 1979. The flora of Canada. Part 4 - Dicotyledoneae (Loasaceae to Compositae). National Museum of Natural Science, Publications in Botany 7: 1117-1711.

Scott, J.K., and F.D. Panetta. 1993. Predicting the Australian weed status of southern African plants. Journal of Biogeography 20: 87-93.

Seiwa, K. 2000. Effects of seed size and emergence time on tree seedling establishment: importance of developmental constraints. Oecologia 123: 208-215.

Sheeley, S.E. 1992. Distribution and life history of Vincetoxicum rossicum (Asclepiadaceae) an exotic plant in North America. Syracuse University of New York, College of Environmental Science and Forestry.

Sheeley, S.E., and D.J. Raynal. 1996. The distribution and status of species of Vincetoxicum in eastern North America. Bulletin of the Torrey Botanical Club 123: $148-156$.

Simons, A.M., and M.O. Johnston. 2000. Variation in seed traits of Lobelia inflata (Campanulaceae): sources and fitness consequences. American Journal of Botany 87: 124-132.

St. Denis, M., and N. Cappuccino. 2004. Reproductive biology of Vincetoxicum rossicum (Kleo.) Barb. (Asclepiadaceae), an invasive alien in Ontario. Journal of the Torrey Botanical Society 131: 8-15.

Stamp, N.E., and J.R. Lucas. 1990. Spatial patterns and dispersal distances of explosively dispersing plants in Florida sandhill vegetation. Journal of Ecology 78: 589-600.

Stanton, M.L. 1984. Seed variation in wild radish: effect of seed size on components of seedling and adult fitness. Ecology 65: 1105-1112. 
Stergios, B.G. 1976. Achene production, dispersal, seed germination, and seedling establishment of Hieracium aurantiacum in an abandoned field community. Canadian Journal of Botany 54: 1189-1197.

Strykstra, R.J., R.M. Bekker, and J.P. Bakker. 1998a. Assessment of dispersule availability: its practical use in restoration management. Acta Botanica Neerlandica 47: 57-70.

Strykstra, R.J., D.M. Pegtel, and A. Bergsma. 1998b. Dispersal distance and achene quality of the rare anemochorous species Arnica montana L.: implications for conservation. Acta Botanica Neerlandica 47: 45-56.

Tyser, R.W. 1992. Vegetation associated with two alien plant species in a fescue grassland in Glacier National Park, Montana. Great Basin Naturalist 52: 189-193.

USDA NRCS. 2004. The PLANTS Database, Version 3.5. National Plant Data Center, Baton Rouge LA 70874-4490 USA. URL: http://plants.usda.gov/cgi_bin/plant_pr ofile.cgi?symbol=CYRO8\&mode=Print Accessed. 7-4-2004.

Usher, M.B. 1988. Biological invasions of nature reserves: a search for generalizations. Biological Conservation 44: 119-135.

Veltman, C.J., S. Nee, and M.J. Crawley. 1996. Correlates of introduction success in exotic New Zealand birds. American Naturalist 147: 542-557.

Venable, D.L., and J.S. Brown. 1988. The selective interactions of dispersal, dormancy, and seed size as adaptations for reducing risk in variable environments. American Naturalist 131: 360-384.

Vermeij, G.J. 1991. When biotas meet: understanding biotic interchange. Science 253: 1099-1104.

Verstraete, M.M., and S.A. Schwartz. 1991. Desertification and global change. Vegetatio 91: 3-13. 
Vitousek, P.M. 1986. Biological invasions and ecosystem properties: can species make a difference? Pages 163-176 in H.A. Mooney, and J.A. Drake, editors. Ecology of biological invasions of North America and Hawaii. Springer-Verlag, New York.

Vitousek, P.M., C.M. D'Antonio, L.L. Loope, M. Rejmanek, and R. Westbrooks. 1997a. Introduced species: a significant component of human-caused global change. New Zealand Journal of Ecology 21: 1-16.

Vitousek, P.M., H.A. Mooney, J. Lubchenco, and J.M. Melillo. 1997b. Human domination of earth's ecosystems. Science 277: 494-499.

Vitousek, P.M., L.R. Walker, L.D. Whiteaker, D. Mueller-Dombois, and P.A. Matson. 1987. Biological invasion by Myrica faya alters ecosystem development in Hawaii. Science 238: 802-803.

Walker, L.R., and P.M. Vitousek. 1991. An invader alters germination and growth of a native dominant tree in Hawaii. Ecology 72: 1449-1455.

Watkinson, A.R. 1978. Demography of a sand dune annual Vulpia fasciculata. III. The dispersal of seeds. Journal of Ecology 66: 483-498.

Webber, M.L. 1934. Fruit dispersal. Malay Forester 3: 18-19.

Webster, C. 2003. Invasive plants in urban environments: City of Toronto control programs. in Canadian Botanical Association, Invasive Plant Symposium, Plant Canada, June 25-29, St. Francis Xavier University, Antigonish, Nova Scotia.

Westoby, M., and B. Rice. 1981. A note on combining two methods of dispersal-fordistance. Australian Journal of Ecology 6: 189-192.

Wilbur, H.M. 1976. Life history evolution in 7 milkweeds of genus Asclepias. Journal of Ecology 64: 223-240. 
Wilbur, H.M. 1977. Propagule size, number, and dispersion pattern in Ambystoma and Asclepias. American Naturalist 111: 43-68.

Wilcove, D.S., D. Rothstein, J. Dubow, A. Phillips, and E. Losos. 1998. Quantifying threats to imperiled species in the United States. BioScience 48: 607-615.

Williamson, M., and A. Fitter. 1996. The varying success of invaders. Ecology 77: 16611666.

Wills, C., R. Condit, R.B. Foster, and S.P. Hubbell. 1997. Strong density- and diversityrelated effects help to maintain tree species diversity in a neotropical forest. Proceedings of the National Academy of Sciences USA 94: 1252-1257.

Wulff, R.D. 1986. Seed size variation an Desmodium paniculatum. II. Effects on seedling growth and physiological performance. Journal of Ecology 74: 99-114.

Zobel, M., E. van der Maarel, and C. Dupré. 1998. Species pool: the concept, its determination and significance for community research. Applied Vegetation Science 1: 55-66. 


\section{Chapter Two: Germination, Survival, and Dispersal}

\section{Introduction}

In the Ottawa region, pale swallow-wort has become a threat to urban green spaces due to its formation of large monocultures over time in areas of colonization, much to the detriment of local flora. Future control strategies may be directed at the early seedling stage of Vincetoxicum rossicum during which the plant is most likely to be vulnerable; at that time the plant has the least developed organs, including root system.

My project looks at the first two years of seedling life as only the first part in a longer length experiment in which individual $V$. rossicum seedlings will be followed through until reproductive maturity.

The first objective of the project was to determine if seed mass influenced the success of $V$. rossicum by measuring a suite of related factors including germination, seedling growth, over-winter survivorship, and presence in the second season after seed planting. The second objective was to evaluate whether the success of $V$. rossicum in dispersal was impeded by greater seed mass. If seed mass affected both seed success and dispersal as expected, I would be able to identify a dispersal-colonization trade-off in V. rossicum.

My investigation of $V$. rossicum had two underlying rationales. 1) Control over dispersal, germination, and seedling survivorship, stages early in the colonization process, may become an important strategy in the future to prevent further spread of this invasive plant. My intent was to parameterize these events. 2) Seed mass has often been proposed as a key quantity linking dispersal to germination processes in a dispersal- 
colonization trade-off. My intent was to identify any strong trade-off in $V$. rossicum as an indicator that colonization events are localized and limited by seed mass. Then I could calculate the effect of such a trade-off as the change in seedling success with dispersal distance as mediated through seed mass. This study differs from previous efforts in a number of ways: Firstly, both the distance of seed trapping and the total trapping effort is larger than nearly all previous dispersal studies. Secondly, a large quantity of individually weighed seeds $(>1000)$ was used for monitoring seedling success after seed planting. I also followed individual seedlings for longer than most germination studies (two years in this case). Thirdly, seedlings were followed in an ecologically realistic environment as opposed to the laboratory or glasshouse methods commonly employed.

I developed a number of predictions about how seed mass might affect dispersal and the various aspects of seedling performance:

1. heavier seeds should be more likely to germinate

2. heavy seeds should produce bigger seedlings (i.e. greater height and leaf length)

3. heavy seeds should produce more polyembryonic sibling seedlings than light seeds

4. early germinators should become bigger seedlings than late germinators

5. seedlings from heavy seeds should better survive the winter to return in the 2 nd year

6. early germinating seeds should produce seedlings better able to survive the winter

7. polyembryony (presence of sibs) should confer greater over-winter survival

8. greater seed mass should predict the presence of a seedling in the second year

9. greater seed mass should restrict the dispersal distance achieved by seeds 


\section{Materials and Methods}

\subsection{Planting the germination garden}

Early in April of 2002, approximately two months before natural germination typically occurs in the field, $V$. rossicum seeds were collected by scraping them off of the surface of the ground. Seeds were separated from dirt and debris, washed under cold water for 1 minute and then air-dried on trays lined with paper towels in a refrigerator at $4^{\circ} \mathrm{C}$ for a week. Then 499 randomly selected seeds were weighed to the nearest $0.1 \mathrm{mg}$ with a Mettler $\mathrm{H} 10$ balance, assigned a unique identification number and placed in a labeled plastic vial. On April 23 all seeds were planted in an experimental field plot of dimension $10 \mathrm{~m}$ by $25 \mathrm{~m}$ in an old field near the Central Experimental Farm, Agriculture and Agrifood Canada, adjacent to the Fletcher Wildlife Conservation Garden and across the Rideau Canal from Carleton University.

The plot consisted of 11 parallel rows of $25 \mathrm{~m}$ length placed $1 \mathrm{~m}$ apart. Within each row, flat, white, plastic label stakes for seeds were placed $0.5 \mathrm{~m}$ apart. On one side of each stake, a randomly selected seed of $V$. rossicum was buried approximately $1 \mathrm{~cm}$ deep in the ground between two upright marking toothpicks at a distance of $5 \mathrm{~cm}$ from one side of the stake. The stake was labeled with the seed identification number. In a separate, unplanned experiment set up one week later, 517 randomly selected seeds were individually placed in labeled vials and planted on the second side of the stake at 5 $\mathrm{cm}$ distance but this time placed on the surface of the soil between another pair of toothpicks. The second experiment was set up because, after dispersal happens, one of two things can happen. A seed can become buried or it can remain on the soil surface. 


\subsection{Seed germination and seedling success}

The germination of seeds and the number of seedlings that arose from each seed in both experiments was recorded every two weeks in the first month after planting and once every month thereafter until the end of September 2002. Non-destructive measurements of seedling growth were taken at these times and additional checks for new germinators were performed. These measures included total height and an estimate of total leaf length performed by summing the lengths of the longest leaf at each node. In cases where individual germinated seeds were polyembryonic, measurements of heights and leaf lengths were summed for all seedlings arising from a single seed before analyses were performed. In May of 2003, survivorship and the presence of new germinants was recorded.

\subsection{Seed dispersal}

In August of 2002, 240 seed traps were built. Each single trap was made of a sheet of PVC poster board $30 \mathrm{~cm}$ by $30 \mathrm{~cm}$ square. To one side of the square I glued shelf paper upside-down with contact cement so that the wax paper backing to the adhesive side of the shelf paper could be peeled off later. After peeling, the adhesive surface became exposed as a sticky-trap to collect seeds. Each trap was nailed into the ground with one 6" steel nail in the center of the trap and a flat steel washer to prevent the nail from slipping through the trap. The effectiveness of this equipment had been established in field tests the previous summer as being highly resistant to degradation by sun and rain. 
Seed traps were placed in an old field bordering a high-density population of $V$. rossicum. This source population for dispersing seeds was comprised of mature plants growing in an approximately $30 \mathrm{~m}$ by $7 \mathrm{~m}$ area underneath and next to a southwest facing forest edge. The limit into the field where plants of the dense population grew was designated to be $0 \mathrm{~m}$. Any mature, colonizing plants growing beyond this distance were removed by hand prior to trapping.

The trapping grid consisted of 16 transects located $2 \mathrm{~m}$ apart and running from 0 $\mathrm{m}$ to $60 \mathrm{~m}$ in the southwest direction perpendicular to the source population of mature $V$. rossicum plants. Trapping was only performed to a distance of $60 \mathrm{~m}$ because shortly after that point was a steep hill. Within a given transect, one trap was placed at distances $0,10,15$, and $20 \mathrm{~m}$ for a total of 16 traps at each of those distances. Two traps were placed side-by-side at 30 and $40 \mathrm{~m}$ for a total of 32 traps at each of those distances. Three traps per transect point were placed at $50 \mathrm{~m}$ for a total of 48 traps and four traps per transect were placed at $60 \mathrm{~m}$ totaling 64 traps at the furthest distance (Figure 1). For two months commencing September 12002 , seeds were picked off the traps daily with tweezers and placed in paper envelopes on which was recorded the date and distance of the trap on which the seed was found. Seeds were then individually weighed back at the laboratory to the nearest $0.1 \mathrm{mg}$. 


\subsection{Germination statistical analyses}

Descriptive statistics on the two seed-germination experiments of seeds were compiled. All data analyses were performed with SAS software, Version 8.1 of the SAS system for Unix. Copyright $(\mathbb{C}$ 1999-2000 SAS Institute Inc. SAS and all other SAS Institute Inc. product or service names are registered trademarks or trademarks of SAS Institute Inc., Cary, NC, USA.

To determine differences between the two planting experiments I performed the median test on all seed masses. Within each planting experiment, $t$-tests were performed to determine differences in mass between germinated and ungerminated seeds. T-tests were also used for finding out if first season germinators (2002) differed in their original seed mass from second year germinators (2003). Then, to determine whether seed mass was important for germination to occur, logistic regressions were performed on each of the two planting experiments. Probabilities of germination were generated for all seed masses in each experiment. T-tests were performed on the original seed masses of the first season germinators segregated coarsely into early (May-June) and late (July-August) germination to see if these groups differed.

Next, the number of successfully germinated embryos per seed recorded was used to categorize and summarize seeds by first season embryony status. Multiple comparisons using one-way ANOVAs with unequal sample sizes followed by post-hoc Scheffe tests allowed me to compare the mean seed masses between seeds that produced 1,2 or 3 or 4 seedlings in each experiment. Due to rarity, the group of seeds that produced 4 seedlings was collapsed into the group producing 3 seedlings. 
Then linear regressions were performed separately on the growth measures of maximum total leaf length and maximum total height with the original seed masses to quantify any relationship that existed. Comparisons between maximum total leaf lengths and maximum total heights of early (May or June) and late (July or August) germinators in the first season of the two experiments were made using t-tests. Only the seedling heights of the above-ground planting experiment required ln-transformation to correct for unequal variances between seedling groups. The Pearson correlation coefficient was calculated between the leaf and height measures for both planting experiments in order to demonstrate the close relationship between the two measures and that they could be used interchangeably in another analysis. Subsequently, only one of the two measures would be used in a logistic regression of survivorship.

\subsection{Survivorship statistical analyses}

The G-test of independence was used to determine whether over-winter survivorship from 2002 to 2003 differed between early and late germinators from 2002 .

Logistic regressions were performed to determine which of original seed mass, maximum total leaf length, maximum total seedling height, or first season embryony status could best predict the subsequent over-winter survivorship of seedlings that would return in 2003. 
Chi-square tests were used to determine if over-winter survivorship was independent of the embryony status recorded in 2002 . In an analysis that that bridged processes occurring from spring 2002 to spring 2003 for all planted seeds, logistic regressions were performed on each planting experiment to assess whether seed mass could predict presence of a seedling in the second season (2003).

\subsection{Dispersal statistical analyses}

For the dispersal data, the information collected on individual seeds included the trapping distance, the seed mass, and whether a seed was filled or unfilled. A linear regression was performed to determine whether the proportion of unfilled $V$. rossicum seeds caught increased with trapping distance away from the propagule source population of adult plants.

Two sets of linear regressions were performed on the seed dispersal data to determine whether seed mass declined with distance. Seeds that I caught at $0 \mathrm{~m}$ were considered undispersed since they were trapped directly underneath parent plants. The first regression analysis included all seeds including those trapped at $0 \mathrm{~m}$. The second regression only included dispersed seeds caught on traps between $10 \mathrm{~m}$ and $60 \mathrm{~m}$. The regression of seed masses and distances of 10 to $60 \mathrm{~m}$ required that two outliers of extremely heavy seeds, both caught at $10 \mathrm{~m}$, be removed. The Spearman rank correlation was also performed on the same two sets of seed masses and dispersal distance data. 


\subsection{Effective dispersal}

The effective dispersal of $V$. rossicum was estimated for each trapping distance in the field. The first season effective dispersal was simply the average probability of germination at each distance calculated as follows. The probability of germination of each seed mass was obtained from the logistic regression of the germination data. For each trapping distance, the predicted probabilities of germination of the seeds caught were averaged to a single value. The same methodology was applied to generate the second season effective dispersal at each distance. The predicted probabilities this time were based on logistic regressions of the probability of presence in 2003.

\section{Results}

\subsection{Germination}

The mean mass of seeds planted below-ground was significantly higher than seeds planted above-ground (Figure 2, median test, d.f. $=1, \mathrm{p}=0.0016)($ Zar 1974). But because of the qualitative difference in treatment between burying seeds and leaving them on the surface, the two experiments were considered separately in subsequent analyses.

The germination rate in the first year within the above-ground planting experiment was $38.4 \%$ and within the below-ground planting experiment it was $70.9 \%$.

In the above-ground experiment, the mean mass of germinators was $5.98 \mathrm{mg}$ and was higher than the $4.97 \mathrm{mg}$ mean for non-germinators (t-test; d.f. $=515 ; \operatorname{Pr}>|\mathrm{t}|=$ $<0.0001$ ). In the below-ground plantings, the difference was not quite as pronounced but 
still quite significant; the mean mass of germinators was $6.40 \mathrm{mg}$ and larger than the mean of $5.68 \mathrm{mg}$ for non-germinators (t-test; d.f. $=498$; $\operatorname{Pr}>|\mathrm{t}|=<0.0001$ ).

Nearly all germination occurred in the first year with considerably fewer new germinators in 2003. Only 43 new seedlings were recorded in the above-ground experiment and only 2 new seedlings in the below-ground planting experiment in the second season. Seeds that germinated one or both of the two years (2002 or 2003) were also heavier than seeds that did not germinate at all over the course of the two years. This was true amongst the above-ground planted seeds (t-test; d.f. $=515 ; \operatorname{Pr}>|t|=$ $<0.0001$ ) and the below-ground planted seeds (t-test; d.f. $=498 ; \operatorname{Pr}>|t|=<0.0001$ ).

Within the above-ground planting experiment, seeds that had initially germinated in 2002 were not different in mass from seeds that initially germinated in 2003 (Figure 3; t-test; d.f. $=241 ; \operatorname{Pr}>|t|=0.4470)$. Seeds in the below-ground plantings had only 3 new germinators in 2003 which prevented comparison of seed masses to the germinators of 2002.

The predicted probability of germination for $V$. rossicum in the below-ground and above-ground planting experiments, as generated by logistic regression (Figure 4), was highly significantly predicted by seed mass (Table 1 ). In both the above-ground and below-ground datasets, the original mean seed mass was not different whether seeds germinated early or late in their first season (Table 2). 


\subsection{Seedling growth}

Of the seeds that germinated in the above-ground and below-ground experiments, most produced one or two seedlings. One seedling was the most likely outcome of germination (Figure 5) and a lesser proportion of seeds produced two seedlings or rarely three or four (Table 3). There was no difference in the original mass of seeds from seedlings that produced one, two, or three to four seedlings. This lack of relationship between seed mass and observed embryony was consistent for both the above-ground planting experiment (Figure 6; d.f. $=197 ; \mathrm{p}=0.114, \mathrm{~F}=2.19, \mathrm{R}^{2}=0.022$ ) and the belowground planting experiment (Figure 7; d.f. $=351 ; \mathrm{p}=0.226, \mathrm{~F}=1.47, \mathrm{R}^{2}=0.004$ ).

Seed mass was positively related to total seedling height in both the above-ground planting experiment (Figure 8; d.f. $=179 ; \mathrm{p}<0.001, \mathrm{~F}=24.20, \mathrm{R}^{2}=0.120$ ) and the below-ground planting experiment (Figure 9; d.f. $=340 ; \mathrm{p}<0.001, \mathrm{~F}=29.52, \mathrm{R}^{2}=$ 0.080 ). Seed mass was also positively related to total seedling leaf length in the aboveground experiment (Figure 10; d.f. $=181 ; \mathrm{p}<0.001, \mathrm{~F}=30.19, \mathrm{R}^{2}=0.144$ ) and in the below-ground experiment (Figure 11; d.f. $=342 ; \mathrm{p}<0.001, \mathrm{~F}=38.74, \mathrm{R}^{2}=0.102$ ).

Also, in both planting experiments, greater first year maximum seedling height and leaf lengths were attained by early germinators as compared to late germinators (Table 4).

The two seedling growth measures, total height and total leaf length, correlated with each other both in the below-ground planting experiment (Figure 12; $\mathrm{r}=0.822$; $\mathrm{P}<0.0001 ; \mathrm{n}=341$ ) and in the above-ground planting experiment (Figure 13; $\mathrm{r}=0.765$; $\mathrm{P}<0.0001 ; \mathrm{n}=180)$. 


\subsection{Survivorship}

For seedlings that germinated in 2002, the over-winter survivorship of seedlings in the above-ground planting experiment was $67.7 \%$ while that of the seedlings in the below-ground planting experiment was $78.2 \%$.

Initial seed mass was not useful in predicting over-winter survivorship of $V$. rossicum seedlings. In the above-ground planting, the best logistic model for survivorship used the maximum total seedling leaf length as the sole predictor (Table 5). In seedlings from below-ground plantings, over-winter survivorship was predicted by maximum total leaf length and initial seed mass (Table 5). However, as the second variable added to the logistic model after leaf length, seed mass was actually slightly negatively related to survivorship and was only marginally significant (Table 5).

The timing of germination did not have a consistent effect on the over-winter survivorship of seedlings. In the above-ground planting experiment, early germinators were favoured with greater survivorship following the winter while seedlings in the below-ground planting experiment displayed no advantage of early germination timing over later relative to their subsequent over-winter survivorship (Table 6).

Over-winter survivorship of seedlings was independent of the first year observed embryony in both the above-ground (Figure 14; Chi Square $=1.856 ; \mathrm{P}=0.395 ; \mathrm{n}=198 ;$ ) and the below-ground planting experiment (Figure 15; Chi Square $=5.193 ; \mathrm{P}=0.075 ; \mathrm{n}$ $=352)$.

Seed mass predicted the presence of a seedling in 2003 in both planting experiments; that is, after two rounds of germination and one round of winter cull (Table 7). In both plantings, larger seeds had a better chance of having at least one seedling 
present in the second year. Censuses in the second year (Table 7) led to a stronger relationship of seedling presence to seed mass in the above-ground planting. That is, fewer seedlings from smaller seeds returned and additional larger seeds germinated in the second year to augment the overall germination success of larger seeds in the first year. There was also a weaker relationship in the below-ground plantings in the second year between seed mass and seedling presence, as compared to censuses in the first year (Table 1). That is, there was a reduced disparity between original seed masses amongst seedlings that returned in the second year (Figure 16) as compared to initial germination successes.

\subsection{Seed dispersal}

Approximately $82.8 \%$ of the seed dispersal data was composed of seeds caught beneath the propagule source population of parent plants at $0 \mathrm{~m}$; this amounts to over 1000 seeds. At $10 \mathrm{~m}$ or more from source, 134 filled seeds were trapped during the season. At trapping distances further than $10 \mathrm{~m}$, the number of filled seeds never exceeded 22 (Figure 17). A higher proportion of unfilled seeds was caught at distances away from source as compared to seeds caught at $0 \mathrm{~m}$. The proportion of unfilled seeds caught on traps at 8 different distances also increased with distance away from the seed source (Figure $18 ; \mathrm{R}^{2}=0.7597 ; \mathrm{F}=18.97 ; \mathrm{P}=0.0048 ; \mathrm{n}=8$ ).

The mass of trapped filled seeds decreased with distance from the propagule source when all the seeds trapped at $0 \mathrm{~m}$ were included in the analysis (Figure $19 ; \mathrm{R}^{2}=$ $0.0159 ; \mathrm{F}=18.42 ; \mathrm{P}<0.0001 ; \mathrm{n}=1692)$. However, the relationship did not remain significant when just the seeds beyond $0 \mathrm{~m}$ were included and two outliers were removed 
(Figure $20 ; \mathrm{R}^{2}=0.0253 ; \mathrm{F}=3.37 ; \mathrm{P}=0.0685 ;$ d.f. $=131$ ). With the two outlier seeds included, the relationship was significant $\left(\mathrm{R}^{2}=0.0358 ; \mathrm{F}=4.90 ; \mathrm{P}=0.0285 ; \mathrm{d} . \mathrm{f} .=133\right)$. Notably, no seeds greater than $7.4 \mathrm{mg}$ in mass were found beyond $10 \mathrm{~m}$ although seeds in that size range had higher germination frequency $(51.5 \%$ in the above-ground set and $81.8 \%$ in the below-ground set of seeds planted) than seeds less in mass. Seeds equal to or less than $7.4 \mathrm{mg}$ had much less germination $(35.2 \%$ and $66.9 \%$ for above-ground and below-ground respectively).

\subsection{Effective dispersal}

For seeds which dispersed beyond $0 \mathrm{~m}$, the average estimated germination probability declined with distance from the source in both the above-ground (Figure 21; ANOVA; F $=21.38 ; \mathrm{R}^{2}=0.810 ; \mathrm{P}=0.0057 ; \mathrm{n}=7$ ) and in the below-ground (Figure $21 ;$ ANOVA; $\mathrm{F}$ $=16.35 ; \mathrm{R}^{2}=0.766 ; \mathrm{P}=0.0099 ; \mathrm{n}=7$ ) experiments. However, the slopes of the relationships were weak with coefficients for distance of -0.00081 and -0.00077 for above- and below-ground data respectively. The difference in probability of germination between experiments was stronger than the relationship between germination and distance within an experiment.

Similarly, the average probability of seedling presence in the second year (2003), based on the earlier logistic regression (Figure 16), declined with distance (Figure 22). The linear regression of these proportions produced significant, slightly negative slopes with coefficients of -0.00078 and -0.0006 for the above-ground (Figure 22; ANOVA; F $=21.42 ; \mathrm{R}^{2}=0.811 ; \mathrm{P}=0.0057 ; \mathrm{n}=7$ ) and the below-ground (Figure 22; ANOVA; $\mathrm{F}=$ $18.47 ; \mathrm{R}^{2}=0.787 ; \mathrm{P}=0.0077 ; \mathrm{n}=7$ ) experiments respectively. 


\section{Discussion}

\subsection{Germination}

Seed size represents the amount of maternal investment in offspring (Roach \& Wulff 1987, Castro 1999). Many workers have tried to determine whether relationships exist between seed mass and a variety of plant characters both inter- and intra-specifically including seed number, seed dispersal, germination, seedling size, and seedling survivorship.

Germination rate is the most straightforward measure of seed success. It has been widely reported that seed mass is positively related to germination rate both in greenhouse experiments (Cavers \& Harper 1966, Weis 1982, Gross 1984) and field experiments (Leishman \& Westoby 1994a, Cideciyan \& Malloch 1982, Morse \& Schmitt 1985) although the converse has been found on rare occasion (e.g. Yanful \& Maun 1996). Previous studies have reported germination percentages in the genus Vincetoxicum. Lumer and Yost (1995) performed laboratory tests that showed $40 \%$ germination for $V$. nigrum seeds produced by autogamy and $49 \%$ germination for open pollinated seeds. Cappuccino et al. (2002) performed greenhouse experiments with $V$. rossicum that showed $44.5 \%$ germination in seeds grown in soil alone and $34.5 \%$ germination in seeds grown in a mixture of grasses.

The current study logically follows from the other two in order to determine what amount of germination can be expected in the field. The rate in the above-ground planting experiment of 38.4 percent was not different from the rates previously reported in the genus. However, the rate of $70.9 \%$ in the below-ground planting experiment was 
surprisingly high considering the less than ideal conditions that field planting involves. After planting, no seeds were watered and rows were not weeded or trimmed. My monthly counts and measurements of the seedlings were the only obvious form of disturbance and that was minimized as much as possible.

Two other emergence-related factors that are positively correlated with seed mass include the ability to emerge from greater soil depths (Harper \& Obeid 1967, Weller 1985, Bond et al. 1999) and the amount of initial root development (Stebbins 1971, Primack 1987, Tilman 1988, Leishman et al. 1995, Westoby et al. 1996). For the current study, seedling root and seedling biomass measures were not taken due to their destructiveness, which would have prevented measuring second-year return rates.

Germination of $V$. rossicum took place over the spring and the summer months with new seedlings emerging as late as July and August. This was consistent with other studies that found that plants that colonized disturbances possessed more late germination capability (Lavorel et al. 1998, Lavorel et al. 1999).

Seed mass did not affect germination date in V. rossicum (Table 1; Table 2). This is contrary to previous findings of Cappuccino et al. (2002), although a lack of association between mass and germination date has been found previously in other species (Shipley \& Parent 1991, Castro 1999, Eriksson 1999). Some authors have found that early germinators were derived from larger seeds than late germinators (Dolan 1984, Simons \& Johnston 2000, Gómez 2004). Other work has demonstrated the importance of emergence date in creating size hierarchies early in the growth of plant populations (Ross \& Harper 1972, Cook 1979, Howell 1981). Seedlings germinating early in the growing season typically attain a larger size by the end of the season (Black 1958, Ross \& Harper 
1972, Abul-Fatih \& Bazzazz 1979, Arnold 1981, Simons \& Johnston 2000). Similarly, early germination of $V$. rossicum in May-June led to increased maximum seedling size as compared to late germination in July-August.

The lack of relationship between embryony status and seed mass in $V$. rossicum has been previously recorded by Cappuccino et al. (2002). However, in other species the opposite has been found to be true. Augspurger (1983) found that the number of embryos in seeds of a tropical tree was related to increased seed weight. I had expected that, in $V$. rossicum grown in the field, additional sibling embryos would confer an overwhelming over-winter survival benefit with multiple seedlings acting as backup offspring against hazards which cause mortality (sensu Garrison \& Augspurger 1983). However, the lack of effect of embryony on survivorship implies that one or both of two things may be occurring. Either the presence of multiple seedlings is not as effective an insurance as seedling size or the hazards that befall seedlings happen such that entire clutches of sibs are killed as to make survival relatively independent of polyembryony.

\subsection{Seedling growth}

The leaves and stems of the seedlings above the ground surface were measured as surrogates for biomass because whole seedling harvesting would have eliminated the possibility of assessment of post-winter survival. The direct benefit of seed mass on the subsequently measured seedling height and leaf length in $V$. rossicum was not unexpected. Previous authors have similarly found seed mass to be positively related to seedling height (Stanton 1984, Mazer 1987, Houssard \& Escarré 1991, Bockstaller \& Girardin 1994), maximum leaf length (Simons \& Johnston 2000), number of leaves 
(Mazer 1987, Houssard \& Escarré 1991, Moegenburg 1996), and leaf area (Stanton 1984, Hendrix et al. 1991, Bockstaller \& Girardin 1994).

Larger seeds have overwhelmingly been found to produce larger seedlings (Wulff 1986, Harper \& Obeid 1967, Weis 1982, Gross 1984, Schemske 1984, Waller 1985, Gross \& Kromer 1986, Roach \& Wulff 1987, Dawson \& Ehleringer 1991, Houssard \& Escarré 1991, Westoby et al. 1992, Bonfil 1998, Chacon \& Bustamante 2001) with only occasional exceptions (Dolan 1984, Zhang \& Hamill 1997).

Further benefit of greater seed mass is conferred early in seedling growth when the plant is at highest risk from various hazards and additional seed reserves allow survival and recovery after hard times. A number of studies have shown seed size to be positively associated with ability to recover from cotyledon damage (Dalling et al. 1997) and herbivory (Bonfil 1998) within a species. Positive relationships of seed mass to likelihood of survival have been described for dry conditions (Leishman \& Westoby 1994b, Salisbury 1942, Westoby et al. 1996, Seiwa et al. 2002), in shade conditions (Saverimuttu \& Westoby 1996, Salisbury 1942, Westoby et al. 1992, Osunkoya et al. 1994, Westoby et al. 1996, Hewitt 1998, Bond et al. 1999) and under nutrient-limited regimes (Leishman \& Westoby 1994a, Leishman \& Westoby 1994b, Jurado \& Westoby 1992, Armstrong \& Westoby 1993, Seiwa 2000). There still is a distinct possibility, though, that some other character or host of characters, which covaries with the seed reserve, is the cause of shade resistance (Kitajima 1996, Leishman \& Westoby 1994a). 


\subsection{Survivorship}

Increased seedling size has been reported to increase survivorship (Black 1956, Harper \& Obeid 1967, Twamley 1967, Austenson \& Walton 1970, Anderson 1971, Haskins \& Gorz 1975, Schaal 1980). This was found to be true for V. rossicum seedlings whereby seedling total leaf length contributed to successful over-winter survivorship.

Polyembryony was not the predictor of survivorship that I had expected it to be. Seedling size was more important to survival in the experiments. However, despite the fact that large seeds produced large seedlings and large seedlings had a greater chance of overwinter survival, there was no direct relationship between seed mass and over-winter survival. This result is consistent with those of authors who have found that the effect of seed size is not persistent, sometimes not even until the end of the first year (Harper \& Obeid 1967, Howe \& Richter 1982, Kromer \& Gross 1987, Salonen \& Suhonen 1995).

The path the plant takes between seed and maturity consists on one hand of diminishing insurance provided by seed mass and, on the other hand, increasing insurance provided by the newly generated organs of the seedling.

\subsection{Dispersal}

Dispersal processes operate for the purpose of transporting offspring to locations away from the parent plant either to avoid maternal competition, avoid mortality from high densities at the home site, andlor avoid pathogens (Janzen 1970, Connell 1971). Increased seedling success has been found at the tail of the dispersal curve (Hamilton \& May 1977, Comins et al. 1980, Platt \& Weis 1985). However, if conditions were 
amenable to growth at the home site because of a specific environmental factor or set of factors, then sites very far from the home site may not permit colonization. Some authors have found this to be the case (Augspurger \& Kitajima 1992, Horvitz \& Schemske 1986).

In many plants, dispersal follows a negative exponential distribution (Stergios 1970, Werner 1975, Augspurger \& Hogan 1983, Okubo \& Levin 1989, Willson 1993), with most propagules falling directly underneath the parent plant. In others, the dispersal abilities of propagules are sufficient to allow most to escape the region directly beneath the parent but not enough to get them beyond a short distance away, where the number of propagules deposited peaks (Salisbury 1942, 1961, Cremer 1965, Levin \& Kerster 1969, 1974, Platt \& Weis 1977).

Sticky traps similar to the ones used in this study have been used elsewhere (Wagner 1965, Werner 1975, Morris et al. 1986). But not all studies involving winddispersed seeds have trapped seeds in the field, although many have done so. Surrogates for linear dispersal distance that have been used include: low speed wind tunnel dispersal distances (Strykstra et al. 1998, Kadareit \& Leins 1988, Van Dorp et al. 1996, Greene \& Johnson 1997, Jongejans \& Schippers 1999, Gravuer et al. 2003), fall rate in a vertical flow tube (Bilanski \& Lal 1965, Law \& Collier 1973, Hofstee 1992), and terminal velocities from dropping seeds from a fall tower in still air (Schulz et al. 1991, Greene \& Johnson 1993, Askew et al. 1997). Under a constant wind speed, fall velocity for example, has predicted dispersal distance (Green 1980, Ernst et al. 1992, Cody \& Overton 1996).

There is more to a seed than just its mass and its falling velocity. Structural features, such as the coma in $V$. rossicum, assist in slowing descent in wind dispersed species. The 
variation in the length and width of these features in relation to the dispersal abilities above have been studied in some species (Augspurger \& Hogan 1983, Guries \& Nordheim 1984, Augspurger 1986). Rarely, the accessory structures have been found to be more important to dispersal than seed mass (Sacchi 1987, Jongejans \& Schippers 1999). Terminal velocity, and hence morphology, has been considered to be more important than seed mass in some wind dispersed species which, like $V$. rossicum, weigh between 0.1 and $2.0 \mathrm{mg}$ (Jongejans \& Schippers 1999). Very low terminal velocity has also been related to seed inviability.

The definition of long distance dispersal (LDD) has varied depending on the study. One reasonable suggestion was for LDD to consist of dispersal events over $100 \mathrm{~m}$ (Cain et al. 2000). At a maximum dispersal distance of $60 \mathrm{~m}$, the current study is definitely medium-range but not many studies have trapped seeds beyond this distance. The tendency as well, has been for such events to possess a special quality or rareness in the conditions under which it occurs or novel mechanism(s) by which seeds get to improbable locations. Since we do not know the true probabilities of LDD for Vincetoxicum, it is hard to tell whether or not LDD is critically important for new colonizations and invasions.

As Muller-Landau et al. (2003) have pointed out, not all species benefit from LDD; species that are common everywhere have nothing to gain while rare species do not need to go that far to escape density and pathogen effects at the home site. LDD may have been nearly ignored in the past, but overemphasis in the present should be cautioned. Seedling establishment after seed arrival is not guaranteed. The total number of seeds produced and released over multiple years at the source and the number of seeds arriving 
to the site of interest must be considered an integral to invasion processes as well. If the seed rain at a site is low most years or non-existent most years then seedling establishment in the long term will become more unlikely.

New methods of measuring dispersal from individuals need to be developed to aid detection of individual seeds dispersed over distances on the order of hundreds of metres at least. Genetic methods might prove useful as a slightly different measure of "effective dispersal" (Cain et al. 2000), but only if invasive populations like V. rossicum are diverse enough genetically to allow for differential markers. This may not be the case if the founding population is based on an exceedingly small number of individuals in a founder effect.

\subsection{Effective dispersal}

Since the dispersal portion of this experiment was used to help determine the effective dispersal, it was considered at the outset whether the effective dispersal could be measured directly using traps of a different type. Rarely, authors have put sterilized trays of soil out in the field and brought the trays back to the greenhouse later in order to directly find out which species are in the seed rain and how many at various distances from source (Archibold 1980, van Baalen 1982, 1983, Denslow \& Diaz 1990). Unfortunately, the soil tray method would have been not only expensive and labour intensive, but also not representative of germination conditions including competitive interactions and soil conditions. At very long distances, the size and/or number of trays required to capture more infrequent dispersers would also have been prohibitive. The benefit of the soil tray is that is actually does detect germination at distance; however, the 
number of seeds that do not germinate is difficult to determine and the conditions are not really not that far removed from those found in a greenhouse experiment.

The next best option available was to evaluate germination of seedlings in quadrats adjacent to seed traps as performed previously by other workers (Wills et al. 1997, Harms et al. 2000). Unfortunately, my high frequency of seed trap checking (ca. once a day) would likely have caused an excessive amount of soil disturbance and, very likely, some accidental trampling of young seedlings. In addition, there is dispersal every year into the field I used to place seed traps. The presence of a significant $V$. rossicum seed bank that would interfere with new dispersal seedling counts is quite possible. The end of the growing season and the beginning of the dispersal season overlapped.

Therefore, my germination garden in a nearby old field was a compromise to both protect seedlings from undue damage and disturbance while still allowing them to experience a more realistic environment in which stresses and limitations occurred.

In $V$. rossicum, effective dispersal based solely on germination consisted of a shallow decline as distance from the seed source increased. From these results I have learned a few things: (1) V.rossicum germinates as successfully in the field as in the greenhouse, (2) the really heavy $V$. rossicum seeds have trouble escaping the parental seed source areas to moderate distances, and (3) the almost non-existent relationship of seed mass to dispersal distance does not point to a dispersal-colonization trade-off operating in $V$. rossicum. The point in (3) is a cautious one because dispersal from parent to landing site was approximate under the seed trap method employed. I was unable to directly measure colonization of individually dispersed seeds but I am confident in linking my dispersal and germination experiments together to provide a snapshot of 
how seed mass may initially affect the colonization process even if that effect may not persist over time. Higher seed mass offsets the higher risk of seedling mortality in the first year, but the first winter is likely the biggest stumbling block to colonization. Older, larger juveniles will be better equipped to survive until some more advanced age where over-winter deaths will be approximately zero.

The longer time span of invasion encompasses more than purely germination. Actually, it underlies my reasoning for determining both the over-winter survivorship and the probability of presence in 2003. After the initial seed input, germination can be considered the first test that individuals must undergo. Hazards such as drought and physical damage that occur during the first growing season are the next. The number of seedlings that died during that time period before the first winter was too small to yield any valuable relationships. The first winter cull is then a mid-stage event that only seedlings derived from germinated seeds can undergo and is therefore only relevant for a subset of the individuals present in the original seed input. Probability of presence in the second season becomes the result of the combination of events causing differential mortality among all individuals. It was my hope to determine whether seedling mortality could be avoided by having such characteristics such as increased seed mass, polyembryony and greater seedling size. While seed mass alone influences the likelihood of germination, the persistence of $V$. rossicum over the winter months, and therefore permanent colonization, is influenced more by seedling size in the first year than by seed mass. Polyembryony itself was not found to play an important role in establishment. 
The effective dispersal estimate based on presence in 2003 (Figure 22) was a lower probability at each distance because the measure itself incorporates more causes of mortality than the estimates based on germination alone (Figure 21).

Some authors have shown that seed mass variation can lead to a dispersalestablishment trade-off (Strykstra et al. 1998, Augspurger \& Hogan 1983, Morse \& Schmitt 1985, Ganeshaiah \& Uma Shaanker 1991, Gravuer et al. 2003). My work does not demonstrate the presence of a trade-off operating in the dispersal and establishment process of the invasive species $V$. rossicum whereby seed mass would limit the dispersal of very large seeds exclusively to short distances. Of the seeds that successfully disperse beyond higher density areas close to the parents, larger seed mass then ceases being a barrier to success. Larger seeds more successfully germinate and initially help develop both the larger leaves and taller heights of their seedlings.

\subsection{Conclusions}

The field germination experiment definitely showed that $V$. rossicum seeds of heavier mass would be more successful initially. However, this was under conditions of low density of conspecifics despite the presence of larger and established grasses. A dispersal-colonization trade-off may only be detectable when poor dispersing seeds undergo density dependent mortality during the seedling stage and when there is a strong positive selection for higher seed mass. With the present data, V. rossicum germination and early success was definitely helped by increased seed mass despite the lack of a strong dispersal relationship to mass. Differences in seed masses caught from $10 \mathrm{~m}$ to 60 $\mathrm{m}$ were too slight to prove conclusively that dispersal was limited by mass. There is the 
possibility that a strong trade-off was not detected. If $V$. rossicum is truly a poor disperser and the density and seedling mortality effects at $0 \mathrm{~m}$ are very strong, then the optimum dispersal distance may occur only slightly beyond $0 \mathrm{~m}$. Such an optimum would maximize both seed mass and dispersal distance.

Alternatively, a trade-off may operate at a larger scale than that of the $60 \mathrm{~m}$ trapping distance employed. More exact dispersal data or inclusion of dispersal data from farther distances, might uncover a threshold distance beyond which even medium sized seeds are unlikely to disperse (sensu Strykstra et al. 1998).

As an invasive plant species of concern in Ontario, V. rossicum in the past has not been considered a major concern (White et al. 1993). In recent years, this has changed (Riley 1989). I have shown in this particular study that the plant is a competent disperser of both small and medium sized seeds, a capable germinator in old-field conditions, and a plant possessing fairly high over-winter survivorship. Over-winter survival and overall presence in the second year after seed input is enhanced by increased seed mass, first year seedling size, but not by polyembryony. No evidence for a $V$. rossicum dispersalcolonization trade-off was found due to no limiting effect of seed mass on the dispersal distances obtained in the field. 


\section{References}

Abul-Fatih, H.A., and F.A. Bazzazz. 1979. The biology of Ambrosia trifida L. II. Germination, emergence, growth, and survival. New Phytologist 83: 817-827.

Anderson, L.B. 1971. Study of some seedling characters and effects of competition on seedlings in diploid and tetraploid red clover (Trifolium pratense L.). New Zealand Journal of Botany 14: 563-571.

Archibold, O.W. 1980. Seed input as a factor in the regeneration of strip-mine wastes in Saskatchewan. Canadian Journal of Botany 58: 1490-1495.

Archibold, O.W., and L. Hume. 1983. A preliminary survey of seed input into fallow fields in Saskatchewan. Canadian Journal of Botany 61: 1216-1221.

Armstrong, D.P., and M. Westoby. 1993. Seedlings from large seeds tolerate defoliation better: a test using phylogenetically independent contrasts. Ecology 74: 10921100.

Arnold, R.M. 1981. Population dynamics and seed dispersal of Chaenorrhinum minus on railroad cinder ballast. American Midland Naturalist 106: 80-91.

Askew, A.P., D. Corker, D.J. Hodkinson, and K. Thompson. 1997. A new apparatus to measure the rate of fall of seeds. Functional Ecology 11: 121-125.

Augspurger, C.K. 1986. Morphology and dispersal potential of wind-dispersed diaspores of neotropical trees. American Journal of Botany 73: 353-363.

Augspurger, C.K., and K.P. Hogan. 1983. Wind dispersal of fruits with variable seed number in a tropical tree (Lonchocarpus pentaphyllus: Leguminosae). American Journal of Botany 70: 1031-1037.

Augspurger, C.K., and K. Kitajima. 1992. Experimental studies of seedling recruitment from contrasting seed distributions. Ecology 73: 1270-1284. 
Austenson, H.M., and P.D. Walton. 1970. Relationships between initial seed weight and mature plant characters in spring wheat. Canadian Journal of Plant Science 50: 53-58.

Bilanski, W.K., and R. Lal. 1965. Behavior of threshed materials in a vertical wind tunnel. Transactions of the American Society of Agricultural Engineers 8: 411 $413,416$.

Black, J.N. 1956. The influence of seed size and depth of sowing on pre-emergence and early vegetative growth of subterranean clover. Australian Journal of Agricultural Research 7: 98-109.

Black, J.N. 1958. Competition between plants of different initial seed sizes in sward of subterranean clover (Trifolium subterraneum L.) with particular reference to leaf area and the light microclimate. Australian Journal of Agricultural Research 9: 299-318.

Bockstaller, C., and P. Girardin. 1994. Effects of seed size on maize growth from emergence to silking. Maydica 39: 213-218.

Bond, W.J., M. Honig, and K.E. Maze. 1999. Seed size and seedling emergence: an allometric relationship and some ecological implications. Oecologia 120: 132136.

Bonfil, C. 1998. The effects of seed size, cotyledon reserves, and herbivory on seedling survival and growth in Quercus rugosa and Q. laurina (Fagaceae). American Journal of Botany 85: 79-87.

Cain, M.L., B.G. Milligan, and A.E. Strand. 2000. Long-distance seed dispersal in plant populations. American Journal of Botany 87: 1217-1227.

Cappuccino, N., R. Mackay, and C. Eisner. 2002. Spread of the invasive alien vine Vincetoxicum rossicum: tradeoffs between seed dispersability and seed quality. American Midland Naturalist 148: 263-270. 
Castro, J. 1999. Seed mass versus seedling performance in Scots pine: a maternally dependent trait. New Phytologist 144: 153-161.

Cavers, P.B., and J.L. Harper. 1966. Germination polymorphism in Rumex crispus and Rumex obtusifolius. Journal of Ecology 54: 367-382.

Chacon, P., and R.O. Bustamante. 2001. The effects of seed size and pericarp on seedling recruitment and biomass in Cryptocarya alba (Lauraceae) under two contrasting moisture regimes. Plant Ecology 152: 137-144.

Cideciyan, M.A., and A.J.C. Malloch. 1982. Effects of seed size on the germination, growth and competitive ability of Rumex crispus and Rumex obtusifolius. Journal of Ecology 70: 227-232.

Cody, M.L., and J.M. Overton. 1996. Short-term evolution of reduced dispersal in island plant populations. Journal of Ecology 84: 53-61.

Comins, H.N., W.D. Hamilton, and R.M. May. 1980. Evolutionarily stable dispersal strategies. Journal of Theoretical Biology 82: 205-230.

Connell, J.H. 1971. On the role of natural enemies in preventing competitive exclusion in some marine animals and in rain forest trees. Pages 298-312 in P.J. Den Boer, and G. Gradwell, editors. Dynamics of populations. PUDOC Scientific Publishers, Wageningen.

Cook, R.E. 1979. Patterns of juvenile mortality and recruitment in plants. Pages 207-231 in O.T. Solbrig, S. Jain, G.B. Johnson, and P.H. Raven, editors. Topics in plant population biology. Columbia University Press, New York.

Cremer, K.W. 1965. Dissemination of seed from Eucalyptus regnans. Australian Forestry 30: 33-37. 
Dalling, J.W., K.E. Harms, and R. Aizprua. 1997. Seed damage tolerance and seedling resprouting ability of Prioria copaifera in Panama. Journal of Tropical Ecology 13: $481-490$.

Dawson, T.E., and J.R. Ehleringer. 1991. Ecological correlates of seed mass variation in Phoradendron juniperinum, a xylem-tapping mistletoe. Oecologia 85: 332-342.

Denslow, J.S., and A.E.G. Diaz. 1990. Seed rain to tree-fall gaps in a neotropical rainforest. Canadian Journal of Forest Research 20: 642-648.

Dolan, R.W. 1984. The effect of seed size and maternal source on individual size in a population of Ludwigia leptocarpa (Onagraceae). American Journal of Botany 71 : 1302-1307.

Eriksson, O. 1999. Seed size variation and its effect on germination and seedling performance in the clonal herb Convallaria majalis. Acta Oecologia 20: 61-66.

Ernst, W.H.O., E.M. Veenendaal, and M.M. Kebakile. 1992. Possibilities for dispersal in annual and perennial grasses in a savanna in Botswana. Vegetatio 102: 1-11.

Ganeshaiah, K.N., and R. Uma Shaanker. 1991. Seed size optimization in a wind dispersed tree Butea monosperma: a trade-off between seedling establishment and pod dispersal efficiency. Oikos 60: 3-6.

Garrison, W.J., and C.K. Augspurger. 1983. Double- and single-seeded acorns of bur oak (Quercus macrocarpa): frequency and some ecological consequences. Bulletin of the Torrey Botanical Club 110: 154-160.

Gómez, J.M. 2004. Bigger is not always better: conflicting selective pressures on seed size in Quercus ilex. Evolution 58: 71-80.

Gravuer, K., E.J. Von Wettberg, and J. Schmitt. 2003. Dispersal biology of Liatris scariosa var. novae-angliae (Asteraceae), a rare New England grassland perennial. American Journal of Botany 90: 1159-1167. 
Green, D.S. 1980. The terminal velocity and dispersal of spinning samaras. American Journal of Botany 67: 1218-1224.

Greene, D.F., and E.A. Johnson. 1993. Seed mass and dispersal capacity in winddispersed diaspores. Oikos 67: 69-74.

Greene, D.F., and E.A. Johnson. 1997. Secondary dispersal of tree seeds on snow. Journal of Ecology 85: 329-340.

Gross, K.L. 1984. Effects of seed size and growth form on seedling establishment of six monocarpic perennial plants. Journal of Ecology 72: 369-387.

Gross, K.L., and M.L. Kromer. 1986. Seed weight effects on growth and reproduction in Oenothera biennis L. Bulletin of the Torrey Botanical Club 113: 252-258.

Guries, R.P., and E.V. Nordheim. 1984. Flight characteristics and dispersal potential of maple samaras. Forest Science 30: 434-440.

Hamilton, W.D., and R.M. May. 1977. Dispersal in stable habitats. Nature 269: 578-581.

Harms, K.E., S.J. Wright, O. Calderon, A. Hernandez, and E.A. Herre. 2000. Pervasive density-dependent recruitment enhances seedling diversity in a tropical forest. Nature 404: 493-495.

Harper, J.L., and M. Obeid. 1967. Influence of seed size and depth of sowing on establishment and growth of varieties of fiber and oil seed flax. Crop Science 7: 527-532.

Haskins, F.A., and H.J. Gorz. 1975. Influence of seed size, planting depth, and companion crop on emergence and vigor of seedlings in sweetclover. Agronomy Journal 67: 652-654. 
Hendrix, S.D., E. Nielsen, T. Nielsen, and M. Schutt. 1991. Are seedlings from small seeds always inferior to seedlings from large seeds? Effects of seed biomass on seedling growth in Pastinaca sativa L. New Phytologist 119: 299-305.

Hewitt, N. 1998. Seed size and shade-tolerance: a comparative analysis of North American temperate trees. Oecologia 114: 432-440.

Hofstee, J.W. 1992. Handling and spreading of fertilizers. II. Physical properties of fertilizer, measuring methods and data. Journal of Agricultural Engineering Research 53: 141-162.

Horvitz, C.C., and D.W. Schemske. 1986. Seed dispersal and environmental heterogeneity in a neotropical herb: a model of population and patch dynamics. Pages 169-186 in A. Estrada, and T.H. Fleming, editors. Frugivores and seed dispersal. Dr. W. Junk Publishers, Dordrecht, Netherlands..

Houssard, C., and J. Escarré. 1991. The effects of seed weight on growth and competitive ability of Rumex acetosella from two successional old-fields. Oecologia 86: 236242.

Howe, H.F., and W.M. Richter. 1982. Effects of seed size on seedling size in Virola surinamensis: a within and between tree analysis. Oecologia 53: 347-351.

Howell, N. 1981. The effect of seed size and relative emergence time on fitness in a natural population of Impatiens capensis Meerb. (Balsaminaceae). American Midland Naturalist 105: 312-320.

Janzen, D.H. 1970. Herbivores and number of tree species in tropical forests. American Naturalist 104: 501-528.

Jongejans, E., and P. Schippers. 1999. Modeling seed dispersal by wind in herbaceous species. Oikos 87: 362-372. 
Jurado, E., and M. Westoby. 1992. Seedling growth in relation to seed size among species of arid Australia. Journal of Ecology 80: 407-416.

Kadareit, J.W., and P. Leins. 1988. A wind tunnel experiment on seed dispersal in Papaver L. sects Argemonidium SPACH and Rhoeadium SPACH (Papaveraceae). Flora 181: 189-203.

Kitajima, K. 1996. Cotyledon functional morphology, seed reserve utilization, and regeneration niches of tropical tree seedlings. Pages 193-208 in M.D. Swaine, editor. The ecology of tropical forest seedlings. UNESCO, Paris.

Kromer, M., and K.L. Gross. 1987. Seed mass, genotype, and density effects on growth and yield of Oenothera biennis L. Oecologia 73: 207-212.

Lavorel, S., C. Rochette, and J.D. Lebreton. 1999. Functional groups for response to disturbance in Mediterranean old fields. Oikos 84: 480-498.

Lavorel, S., B. Touzard, J.D. Lebreton, and B. Clement. 1998. Identifying functional groups for response to disturbance in an abandoned pasture. Acta Oecologia 19: 227-240.

Law, S.E., and J.A. Collier. 1973. Aerodynamic resistance coefficients of agricultural particulates determined by elutriation. Transactions of the American Society of Agricultural Engineers 16: 918-921.

Leishman, M.R., and M. Westoby. 1994a. The role of large seed size in shaded conditions: experimental evidence. Functional Ecology 8: 205-214.

Leishman, M.R., and M. Westoby. 1994b. The role of seed size in seedling establishment in dry soil conditions: experimental evidence from semi-arid species. Journal of Ecology 82: 249-258.

Leishman, M.R., M. Westoby, and E. Jurado. 1995. Correlates of seed size variation: a comparison among five temperate floras. Journal of Ecology 83: 517-530. 
Levin, D.A., and H. Kerster. 1969. Density-dependent gene dispersal in Liatris. American Naturalist 103: 61-74.

Levin D.A. \& Kerster H.W. 1974. Gene flow in seed plants. Pages 139-220 in T. Dobzhansky, M.K. Hecht, and W.C. Steere, editors. Evolutionary Biology [7], New York, Plenum Press.

Lumer, C., and S.E. Yost. 1995. The reproductive biology of Vincetoxicum nigrum (L.) Moench. (Asclepiadaceae), a Mediterranean weed in New York State. Bulletin of the Torrey Botanical Club 122: 15-23.

Mazer, S.J. 1987. The quantitative genetics of life-history and fitness components in Raphanus raphanistrum L. (Brassicaceae): ecological and evolutionary consequences of seed-weight variation. American Naturalist 130: 891-914.

Moegenburg, S.M. 1996. Sabal palmetto seed size: causes of variation, choices of predators, and consequences for seedlings. Oecologia 106: 539-543.

Morris, W.F., P.L. Marks, C.L. Mohler, N.R. Rappaport, F.R. Wesley, and M.A. Moran. 1986. Seed dispersal and seedling emergence in an old-field community in central New York (USA). Oecologia 70: 92-99.

Morse, D.H., and J. Schmitt. 1985. Propagule size, dispersal ability, and seedling performance in Asclepias syriaca. Oecologia 67: 372-379.

Muller-Landau, H.C., S.A. Levin, and J.E. Keymer. 2003. Theoretical perspectives on evolution of long-distance dispersal and the example of specialized pests. Ecology 84: $1957-1967$.

Okubo, A., and S.A. Levin. 1989. A theoretical framework for data-analysis of wind dispersal of seeds and pollen. Ecology 70: 329-338. 
Osunkoya, O.O., J.E. Ash, M.S. Hopkins, and A.W. Graham. 1994. Influence of seed size and seedling ecological attributes on shade-tolerance of rain-forest tree species in Northern Queensland. Journal of Ecology 82: 149-163.

Platt, W.J., and I.M. Weis. 1977. Resource partitioning and competition within a guild of fugitive prairie plants. American Naturalist 111: 479-513.

Platt, W.J., and I.M. Weis. 1985. An experimental study of competition among fugitive prairie plants. Ecology 66: 708-720.

Primack, R.B. 1987. Relationships among flowers, fruits, and seeds. Annual Review of Ecology and Systematics 18: 409-430.

Riley, J.L. 1989. More invasive aliens. Seasons 29: 23.

Roach, D.A., and R.D. Wulff. 1987. Maternal effects in plants. Annual Review of Ecology and Systematics 18: 209-235.

Ross, M.A., and J.L. Harper. 1972. Occupation of biological space during seedling establishment. Journal of Ecology 60: 77-88.

Sacchi, C.F. 1987. Variability in dispersal ability of common milkweed, Asclepias syriaca, seeds. Oikos 49: 191-198.

Salisbury, E. 1942. The reproductive capacity of plants: studies in quantitative biology. G. Bell and Sons, London, UK.

Salisbury, E. 1961. Weeds and aliens. Collins, London, UK.

Salonen, V., and J. Suhonen. 1995. Effects of seed weight on growth, reproduction and competitive ability of Linum usitatissimum seedlings. Annales Botanici Fennici 32:101-106. 
Saverimuttu, T., and M. Westoby. 1996. Components of variation in seedling potential relative growth rate: phylogenetically independent contrasts. Oecologia 105: 281285.

Schaal, B.A. 1980. Reproductive capacity and seed size in Lupinus texensis. American Journal of Botany 67: 703-709.

Schemske, D.W. 1984. Population structure and local selection in Impatiens pallida (Balsaminaceae), a selfing annual. Evolution 38: 817-832.

Schulz, B., J. Doering, and G. Gottsberger. 1991. Apparatus for measuring the fall velocity of anemochorous diaspores, with results from two plant communities. Oecologia 86: 454-456.

Seiwa, K. 2000. Effects of seed size and emergence time on tree seedling establishment: importance of developmental constraints. Oecologia 123: 208-215.

Seiwa, K., A. Watanabe, T. Saitoh, H. Kanno, and S. Akasaka. 2002. Effects of burying depth and seed size on seedling establishment of Japanese chestnuts, Castanea crenata. Forest Ecology and Management 164: 149-156.

Shipley, B., and M. Parent. 1991. Germination responses of 64 wetland species in relation to seed size, minimum time to reproduction and seedling relative growth rate. Functional Ecology 5: 111-118.

Simons, A.M., and M.O. Johnston. 2000. Variation in seed traits of Lobelia inflata (Campanulaceae): sources and fitness consequences. American Journal of Botany 87: 124-132.

Stanton, M.L. 1984. Seed variation in wild radish: effect of seed size on components of seedling and adult fitness. Ecology 65: 1105-1112.

Stebbins, G.L. 1971. Adaptive radiation of reproductive characteristics in angiosperms. II. Seeds and seedlings. Annual Review of Ecology and Systematics 2: 237-260. 
Stergios, B.G. 1970. Seed dispersal, seed germination, and seedling establishment of Hieracium aurantiacum in an old field community. Michigan State University. M.Sc. Thesis.

Strykstra, R.J., D.M. Pegtel, and A. Bergsma. 1998. Dispersal distance and achene quality of the rare anemochorous species Arnica montana L.: implications for conservation. Acta Botanica Neerlandica 47: 45-56.

Tilman D. 1988. Plant strategies and the dynamics and structure of plant communities. Pages 1-360 in S.A. Levin, and H.S. Horn, editors. Monographs in Population Biology [26], Princeton, NJ, Princeton University Press.

Twamley, B.E. 1967. Seed size and seedling vigor in birdsfoot trefoil. Canadian Journal of Plant Science 47: 603-609.

van Baalen, J. 1982. Germination ecology and seed population dynamics of Digitalis purpurea. Oecologia 53: 61-67.

Van Dorp, D., W.P.M. Van den Hoek, and C. Daleboudt. 1996. Seed dispersal capacity of six perennial grassland species measured in a wind tunnel at varying wind speed and height. Canadian Journal of Botany 74: 1956-1963.

Wagner, R.H. 1965. The annual seed rain of adventive herbs in a radiation damaged forest. Ecology 46: 517-520.

Waller, D.M. 1985. The genesis of size hierarchies in seedling populations of Impatiens capensis Meerb. New Phytologist 100: 243-260.

Weis, I.M. 1982. The effects of propagule size on germination and seedling growth in Mirabilis hirsuta. Canadian Journal of Botany 60: 1868-1874.

Weller, S.G. 1985. Establishment of Lithospermum caroliniense on sand dunes: the role of nutlet mass. Ecology 66: 1893-1901. 
Werner, P.A. 1975. A seed trap for determining patterns of seed deposition in terrestrial plants. Canadian Journal of Botany 53: 810-813.

Westoby, M., E. Jurado, and M. Leishman. 1992. Comparative evolutionary ecology of seed size. Trends in Ecology \& Evolution 7: 368-372.

Westoby, M., M. Leishman, and J. Lord. 1996. Comparative ecology of seed size and dispersal. Philosophical Transactions of the Royal Society of London. Series B: Biological Sciences 351: 1309-1318.

White D.J., E. Haber, and C. Keddy 1993. Invasive plants of natural habitats in Canada: an integrated review of wetland and upland species and legislation governing their control. Pages 1-121. Ottawa, Canadian Wildlife Service.

Wills, C., R. Condit, R.B. Foster, and S.P. Hubbell. 1997. Strong density- and diversityrelated effects help to maintain tree species diversity in a neotropical forest. Proceedings of the National Academy of Sciences USA 94: 1252-1257.

Willson, M.F. 1993. Dispersal mode, seed shadows, and colonization patterns. Vegetatio 107/108: $261-280$.

Wulff, R.D. 1986. Seed size variation in Desmodium paniculatum. III. Effects on reproductive yield and competitive ability. Journal of Ecology 74: 115-121.

Yanful, M., and M.A. Maun. 1996. Effects of burial of seeds and seedlings from different seed sizes on the emergence and growth of Strophostyles helvola. Canadian Journal of Botany 74: 1322-1330.

Zar, J.H. 1974. Biostatistical analysis, Prentice-Hall, Englewood Cliffs, NJ.

Zhang, J., and A.S. Hamill. 1997. Seed weight, intraspecific competition, and plant performance in Abutilon theophrasti. Canadian Journal of Botany 75: 1614-1620. 
Table 1. Results of logistic regression of the probability of $V$. rossicum germination on the independent variable seed mass in the above -ground and below-ground planting experiments.

\begin{tabular}{|l|l|c|c|c|c|}
\hline $\begin{array}{l}\text { planting } \\
\text { experime } \\
\text { nt }\end{array}$ & $\begin{array}{l}\text { Independent } \\
\text { variable }\end{array}$ & $\begin{array}{c}\text { Parameter } \\
\text { estimate }\end{array}$ & $\begin{array}{l}\text { Odds } \\
\text { ratio }\end{array}$ & $\begin{array}{c}\text { Chi- } \\
\text { square }\end{array}$ & $\begin{array}{c}\text { Prob }> \\
\text { Chi- } \\
\text { square }\end{array}$ \\
\hline $\begin{array}{l}\text { above- } \\
\text { ground }\end{array}$ & whole model & & & 26.5451 & $<0.0001$ \\
\cline { 2 - 6 } & seed mass & 0.0235 & 1.024 & 25.1756 & $<0.0001$ \\
\hline \multirow{2}{*}{$\begin{array}{l}\text { below- } \\
\text { ground }\end{array}$} & whole model & & & 16.7626 & $<0.0001$ \\
\cline { 2 - 6 } & seed mass & 0.0233 & 1.024 & 15.9827 & $<0.0001$ \\
\hline
\end{tabular}

Table 2. Seed mass (mg) of early and late germinating $V$. rossicum seeds in the above-ground and below-ground planting experiments. Means (+/- SE) and $\mathrm{P}$-values for $\mathrm{t}$-tests comparing early versus late germinators are reported.

\begin{tabular}{|l|c|c|c|c|}
\cline { 3 - 5 } \multicolumn{1}{c|}{} & \multicolumn{2}{c|}{ initial seed mass $(\mathrm{mg})$} & \multicolumn{1}{c}{} \\
\hline Experiment & $\mathrm{N}$ & early & late & $\mathrm{P}$ \\
\hline above-ground & 198 & $5.966+/-0.155$ & $5.848+/-0.286$ & 0.7071 \\
\hline below-ground & 353 & $6.529+/-0.137$ & $6.301+/-0.630$ & 0.2259 \\
\hline
\end{tabular}

Table 3. Percent germination of $V$. rossicum seeds in the two planting experiments grouped according to the recorded number of seedlings per seed (observed embryony).

\begin{tabular}{|c|c|c|}
\hline & \multicolumn{2}{|c|}{ Planting Experiment } \\
\hline seedlings per seed & above-ground & below-ground \\
\hline 1 & $53.54 \%$ & $54.67 \%$ \\
\hline 2 & $38.89 \%$ & $38.53 \%$ \\
\hline 3 & $6.57 \%$ & $6.23 \%$ \\
\hline 4 & $1.01 \%$ & $0.28 \%$ \\
\hline
\end{tabular}


Table 4. Total heights $(\mathrm{cm})$ and leaf lengths $(\mathrm{mm})$ of early and late germinating $V$. rossicum seeds in the above-ground and below-ground planting experiments. Means ( $+/-\mathrm{SE})$ and $\mathrm{P}$-values for $\mathrm{t}$-tests comparing early versus late germinators are reported.

\begin{tabular}{|l|l|c|r|c|c|c|}
\hline Expt & Variable & $\mathrm{N}$ early & early & N late & late & $\mathrm{P}$ \\
\hline above & $\ln$ (height) & 135 & $1.82+/-0.03$ & 45 & $1.49+/-0.06$ & $<0.0001$ \\
\cline { 2 - 7 } & leaf & 135 & $27.07+/-0.91$ & 45 & $18.24+/-1.29$ & $<0.0001$ \\
\hline \multirow{2}{*}{ below } & height & 152 & $6.32+/-0.18$ & $187^{*}$ & $5.48+/-0.17$ & 0.0010 \\
\cline { 2 - 7 } & leaf & 152 & $33.64+/-1.09$ & 189 & $26.16+/-0.96$ & 0.0001 \\
\hline
\end{tabular}

* missing height values for 2 seedlings

Table 5. Results of stepwise logistic regression of the probability of $V$. rossicum over-winter survivorship on the independent variables seed mass, early or late germination, observed embryony, and total leaf length in the above-ground and below-ground planting experiments.

\begin{tabular}{|l|l|c|c|c|c|}
\hline $\begin{array}{l}\text { planting } \\
\text { experiment }\end{array}$ & $\begin{array}{l}\text { Independent } \\
\text { variable }\end{array}$ & $\begin{array}{c}\text { Parameter } \\
\text { estimate }\end{array}$ & Odds ratio & Chi-square & $\begin{array}{c}\text { Prob }>\text { Chi- } \\
\text { square }\end{array}$ \\
\hline \multirow{2}{*}{$\begin{array}{l}\text { above- } \\
\text { ground }\end{array}$} & whole model & & & 9.2981 & 0.0023 \\
\cline { 2 - 6 } & leaf length & 0.0510 & 1.052 & 8.2895 & 0.0040 \\
\hline \multirow{2}{*}{$\begin{array}{l}\text { below- } \\
\text { ground }\end{array}$} & whole model & & & 88.7185 & $<0.0001$ \\
\cline { 2 - 6 } & leaf length & 0.1451 & 1.156 & 57.8348 & $<0.0001$ \\
\cline { 2 - 6 } & early or late & -0.7721 & 0.462 & 4.9082 & 0.0267 \\
\cline { 2 - 6 } & seed mass & -0.0208 & 0.979 & 4.4143 & 0.0356 \\
\cline { 2 - 6 } & embryony & -0.6308 & 0.532 & 3.8616 & 0.0494 \\
\hline
\end{tabular}

Table 6. Likelihood-ratio chi-square tests of independence (G-tests) of $V$. rossicum over-winter survival versus early or late germination for the aboveground and below-ground planting experiments. Counts of seedlings, $\mathrm{G}$-values, and P-values are reported.

\begin{tabular}{|c|c|c|c|c|c|}
\hline Experiment & over-winter survival & early & late & G & P \\
\hline above-ground & yes & 40 & 108 & 7.2368 & 0.0071 \\
\cline { 2 - 5 } & no & 24 & 26 & & \\
\hline below-ground & yes & 33 & 122 & 0.0443 & 0.8332 \\
\cline { 2 - 4 } & no & 44 & 154 & & \\
\hline
\end{tabular}


Table 7. Results of logistic regressions of the probability of $V$. rossicum 2nd year presence (2003) on the independent variable seed mass in the below-ground and above-ground planting experiments.

\begin{tabular}{|l|l|c|c|c|c|}
\hline $\begin{array}{l}\text { planting } \\
\text { experiment }\end{array}$ & $\begin{array}{l}\text { Independent } \\
\text { variable }\end{array}$ & $\begin{array}{c}\text { Parameter } \\
\text { estimate }\end{array}$ & Odds ratio & Chi-square & $\begin{array}{c}\text { Prob }>\text { Chi- } \\
\text { square }\end{array}$ \\
\hline \multirow{2}{*}{$\begin{array}{l}\text { above- } \\
\text { ground }\end{array}$} & whole model & & & 33.2525 & $<0.0001$ \\
\cline { 2 - 6 } & seed mass & 0.0269 & 1.027 & 31.0416 & $<0.0001$ \\
\hline \multirow{2}{*}{$\begin{array}{l}\text { below- } \\
\text { ground }\end{array}$} & whole model & & & 9.6713 & 0.0019 \\
\cline { 2 - 6 } & seed mass & 0.0160 & 1.016 & 9.4405 & 0.0021 \\
\hline
\end{tabular}

Table 8. Spearman rank correlation for $V$. rossicum seed mass and dispersal distance including seeds trapped at $0 \mathrm{~m}$ from seed source plants.

\begin{tabular}{|l|l|}
\hline & Distance \\
\hline Correlation Coefficient & -0.098 \\
\hline Significance & 0.001 \\
\hline $\mathrm{N}$ & 1144 \\
\hline
\end{tabular}

Table 9. Spearman rank correlation for $V$. rossicum seed mass and dispersal distance excluding seeds trapped at $0 \mathrm{~m}$ from seed source plants.

\begin{tabular}{|l|l|}
\hline & Distance \\
\hline Correlation Coefficient & -0.159 \\
\hline Significance & 0.048 \\
\hline $\mathrm{N}$ & 134 \\
\hline
\end{tabular}




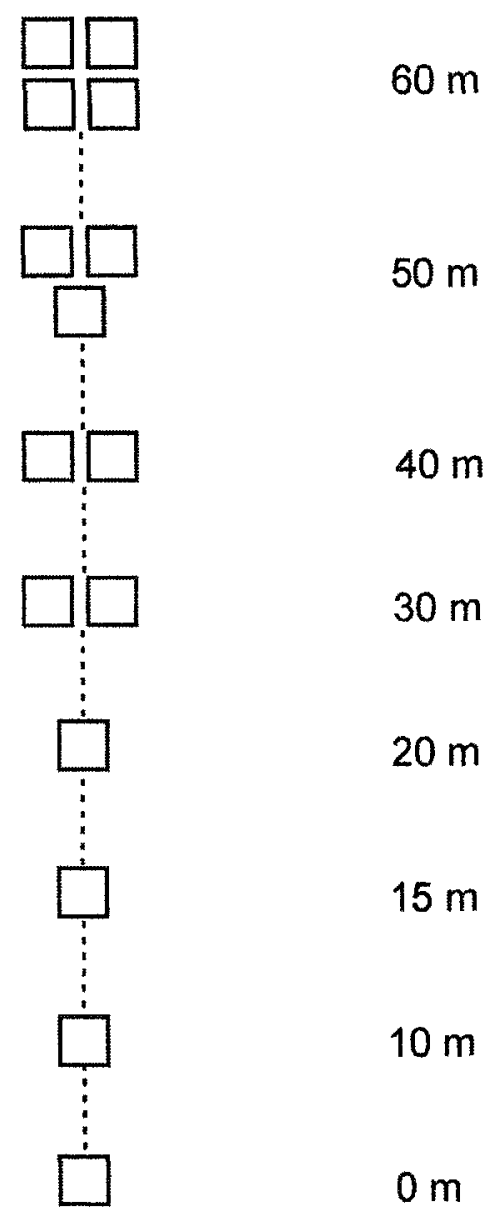

Figure 1. One of 16 transects in which each contains 15 seed traps placed at various distances for recording the dispersal of $V$. rossicum seeds in the fall of 2002. 


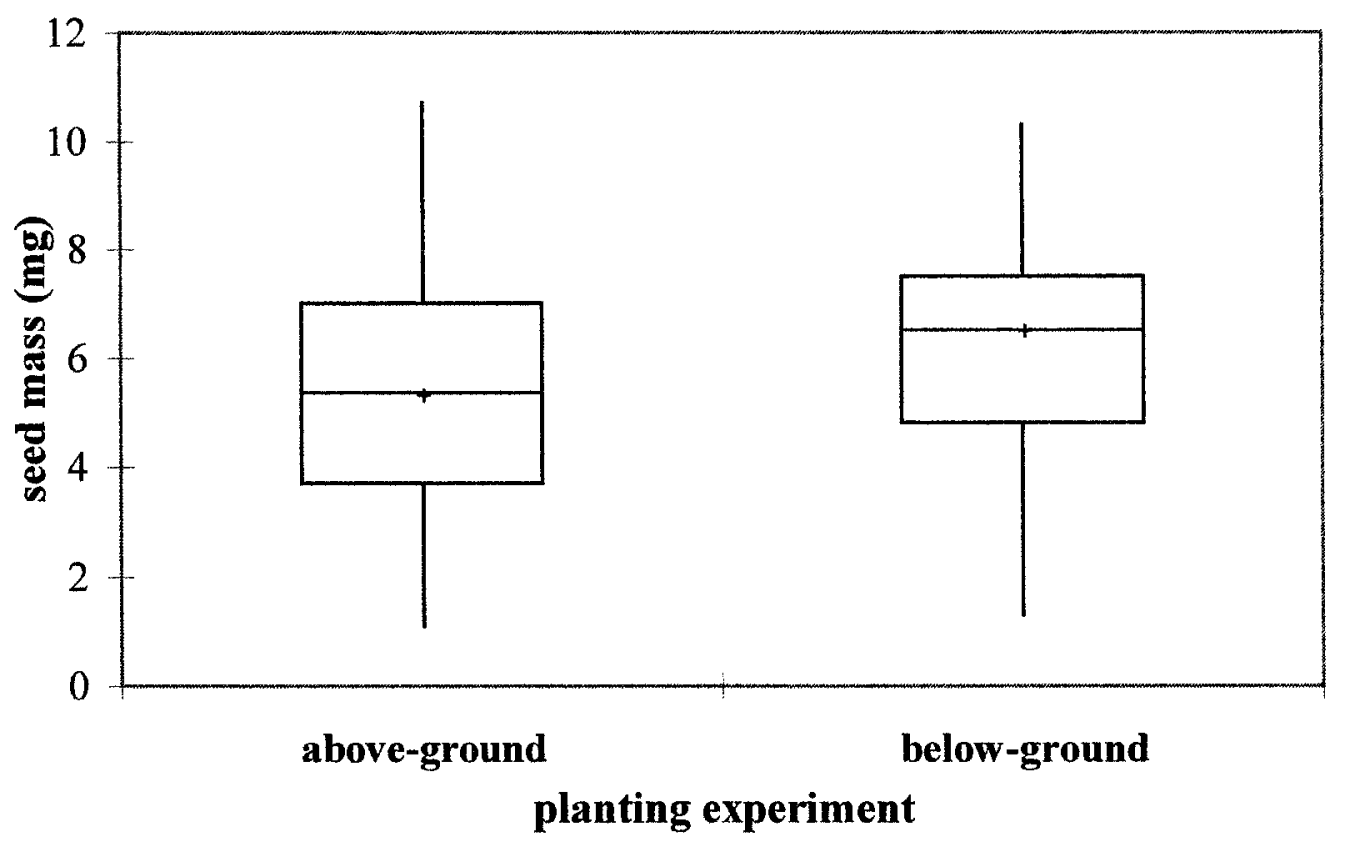

Figure 2. V. rossicum seed mass in the above ground and belowground planting experiments. Mean is represented by $(+)$.

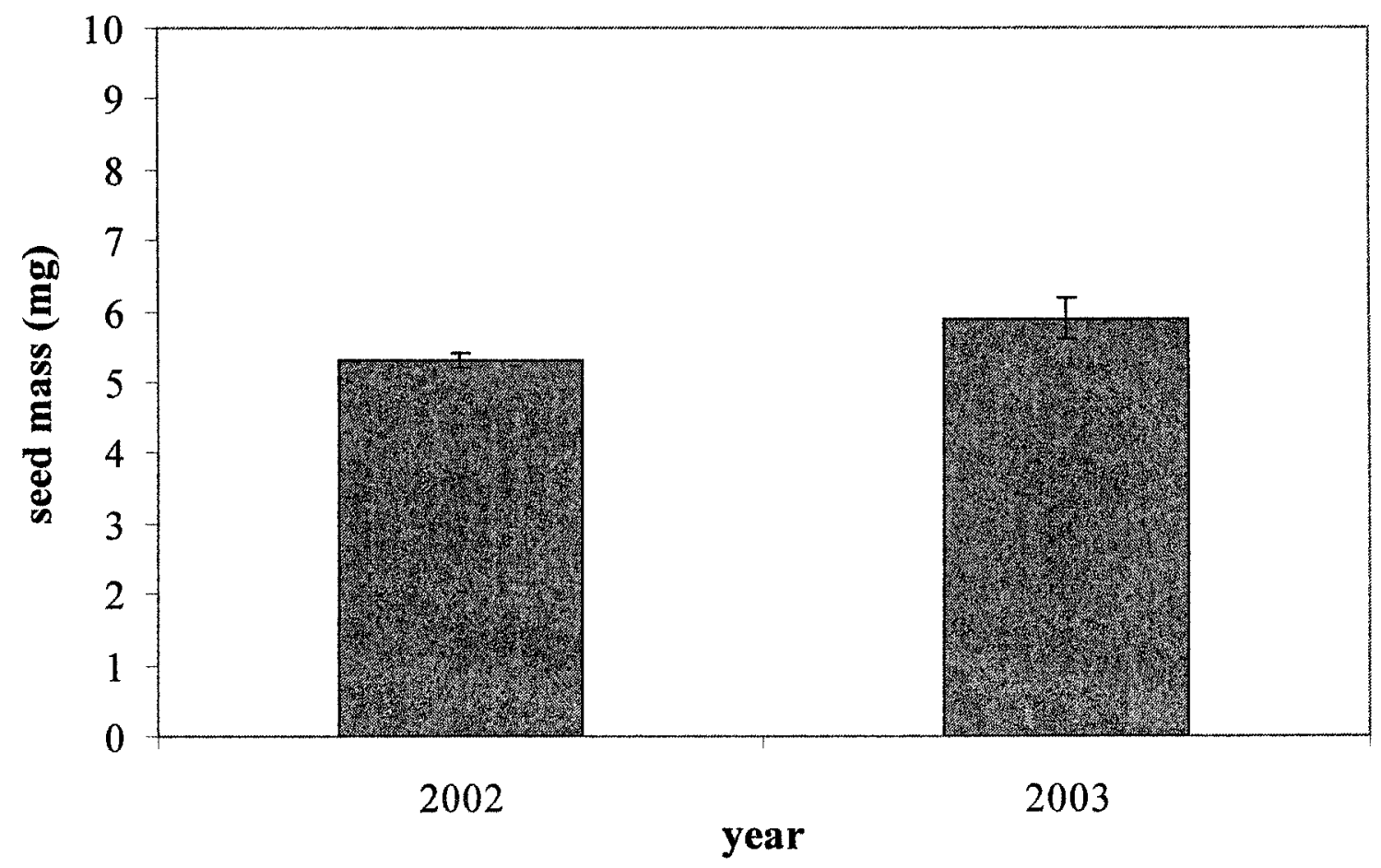

Figure 3. Mean seed mass of $V$. rossicum first-time germinators in the above-ground experiment did not differ between the first season (2002) and the second season (2003). 


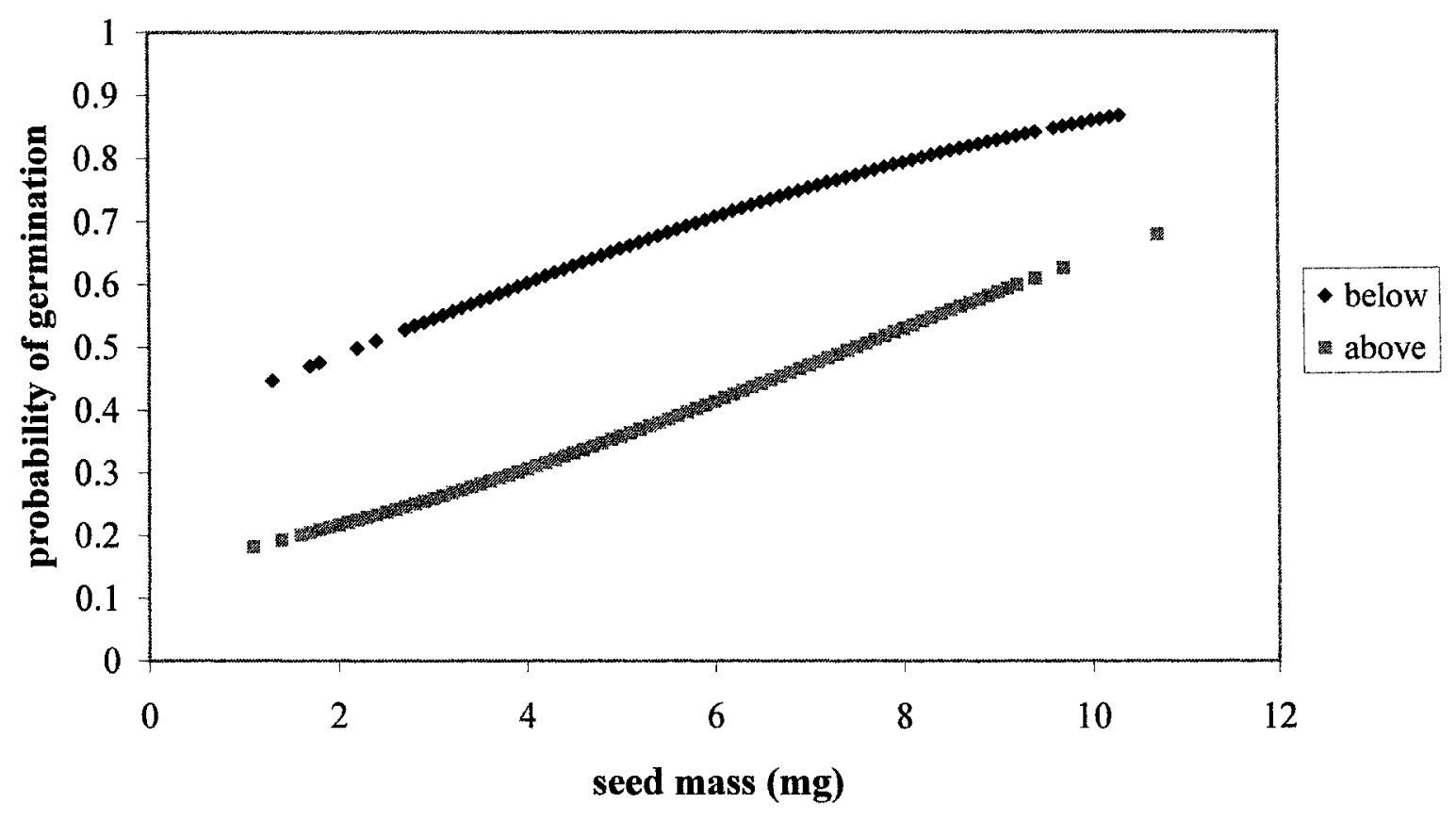

Figure 4. Logistic regression of the probability of seed germination on seed mass in the first growing season for the aboveand below-ground $V$. rossicum planting experiments.

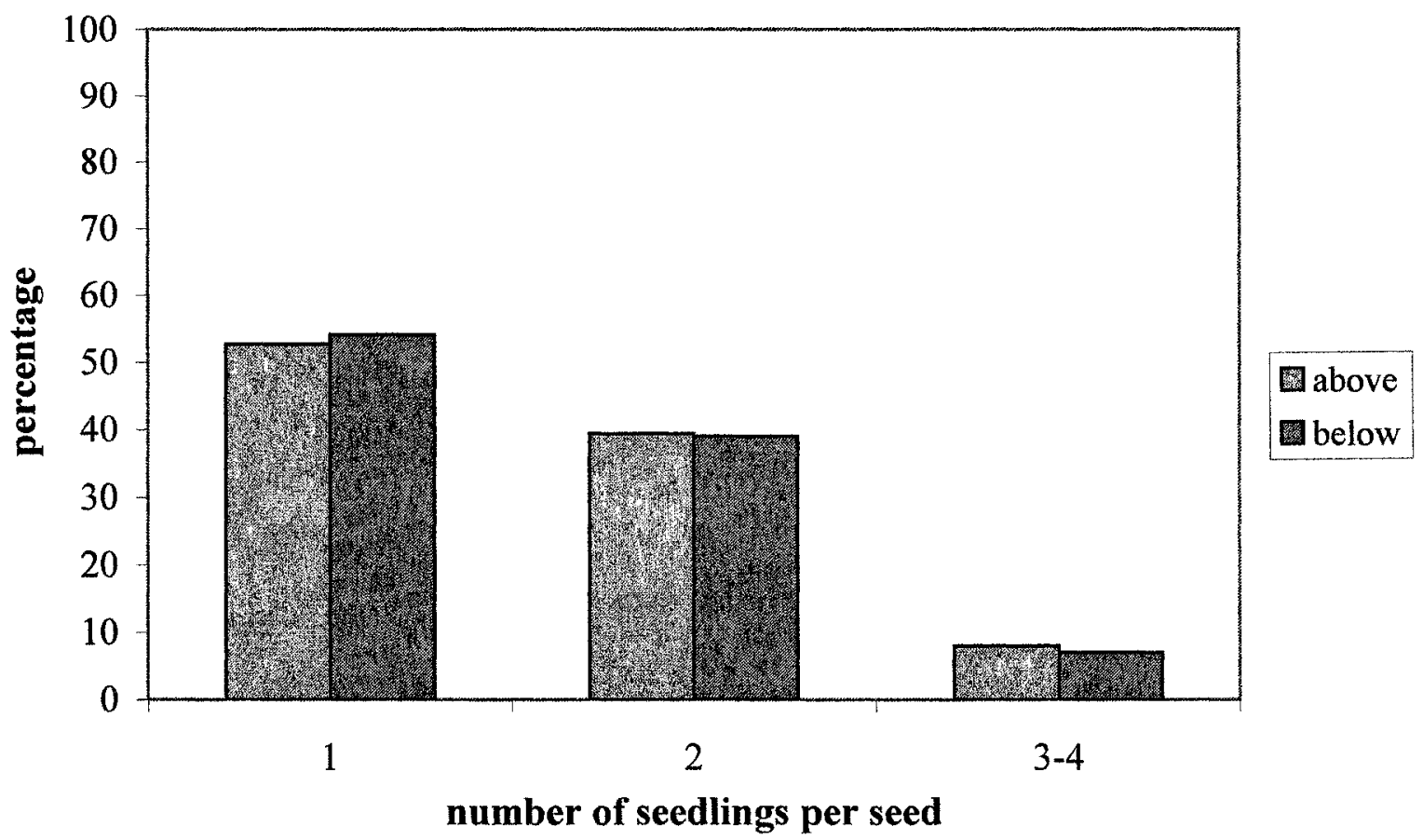

Figure 5. Percentage embryony status in the first season of germinated $V$. rossicum seeds in both planting experiments. 


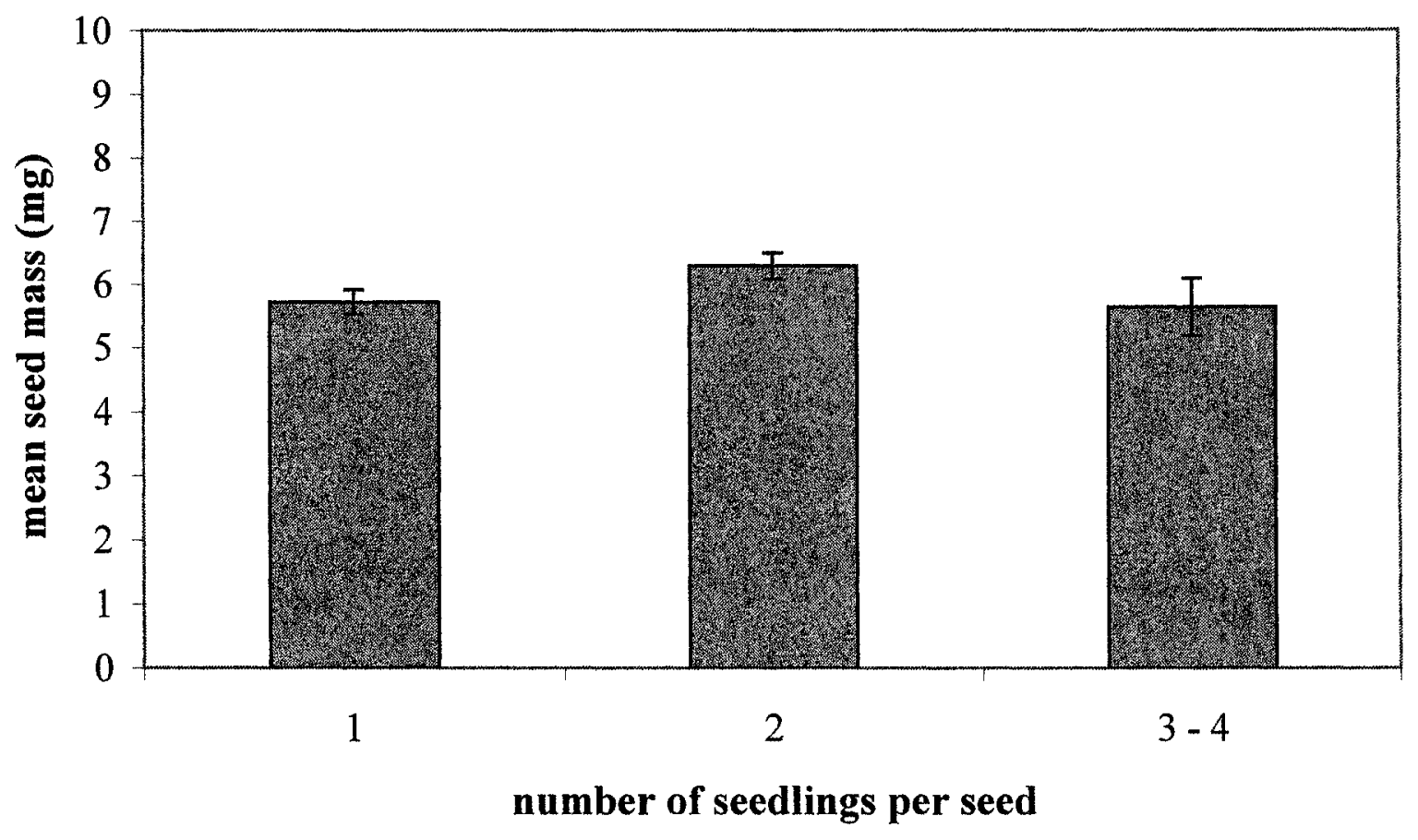

Figure 6. Mean seed mass of above-ground planted $V$. rossicum seeds with different numbers of germinated embryos.

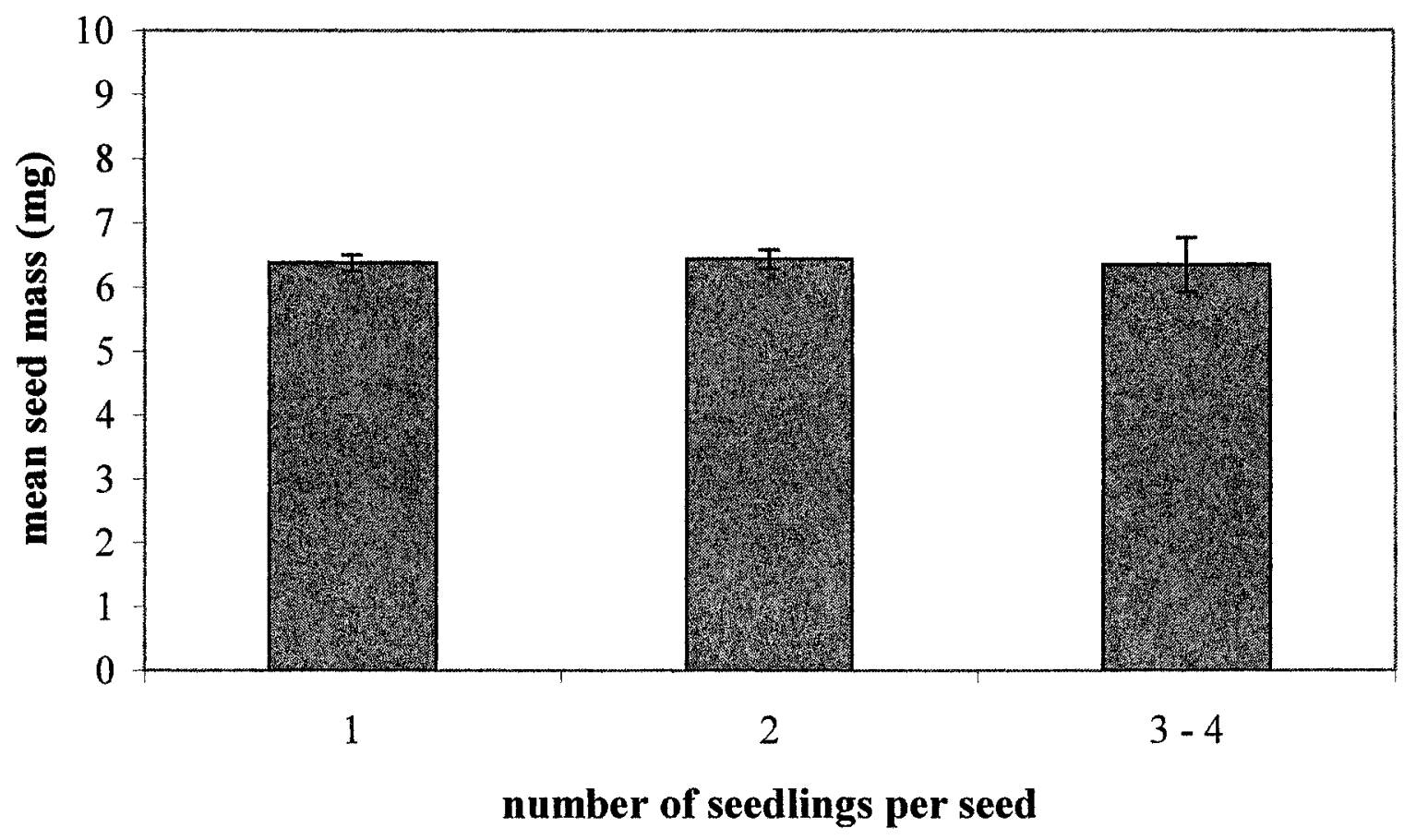

Figure 7. Mean seed masses of below-ground planted $V$. rossicum seeds with different numbers of germinated seedlings (season 1). 


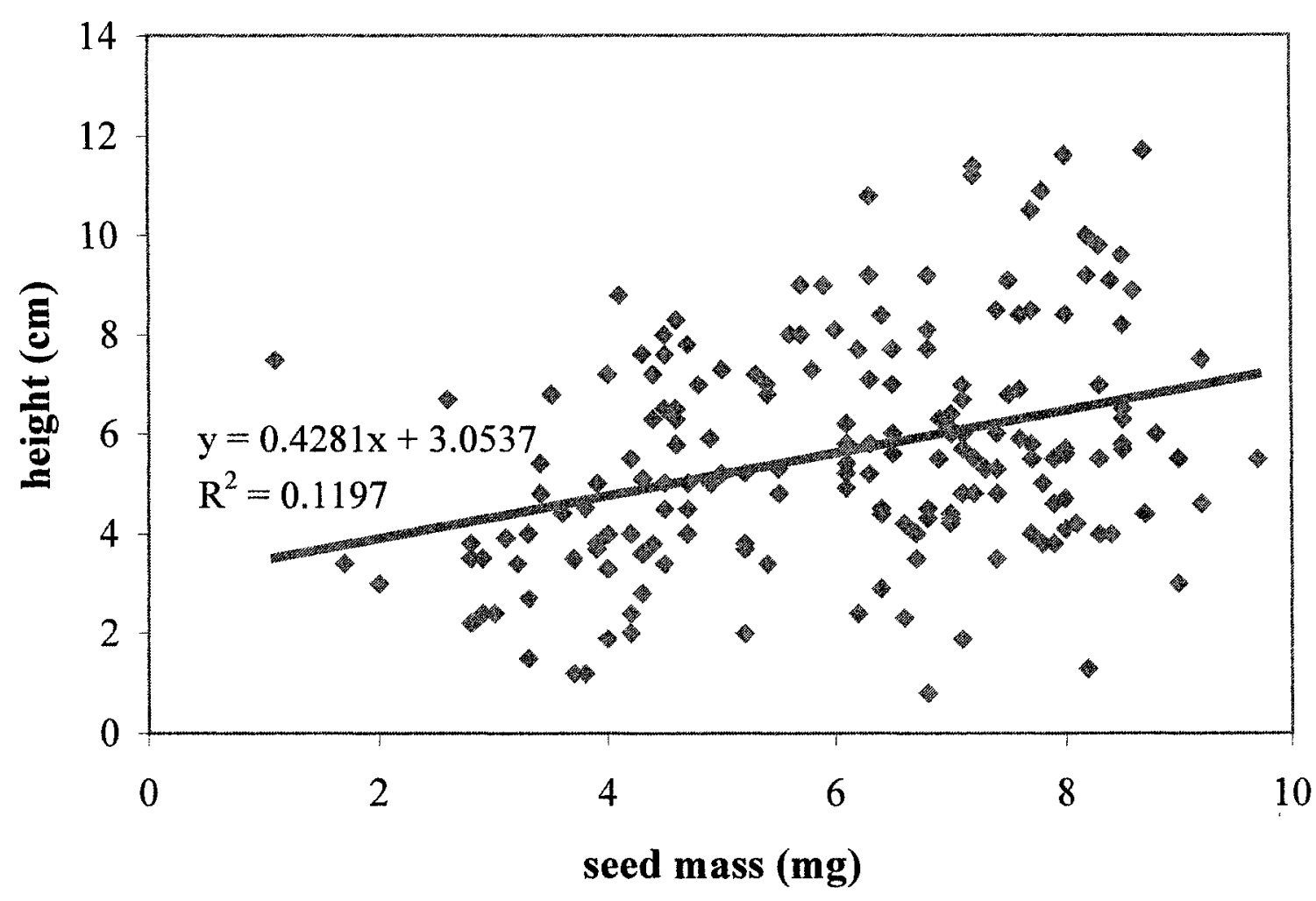

Figure 8. Maximum total height attained by $V$. rossicum seedlings from above-ground plantings in the first season predicted by seed mass.

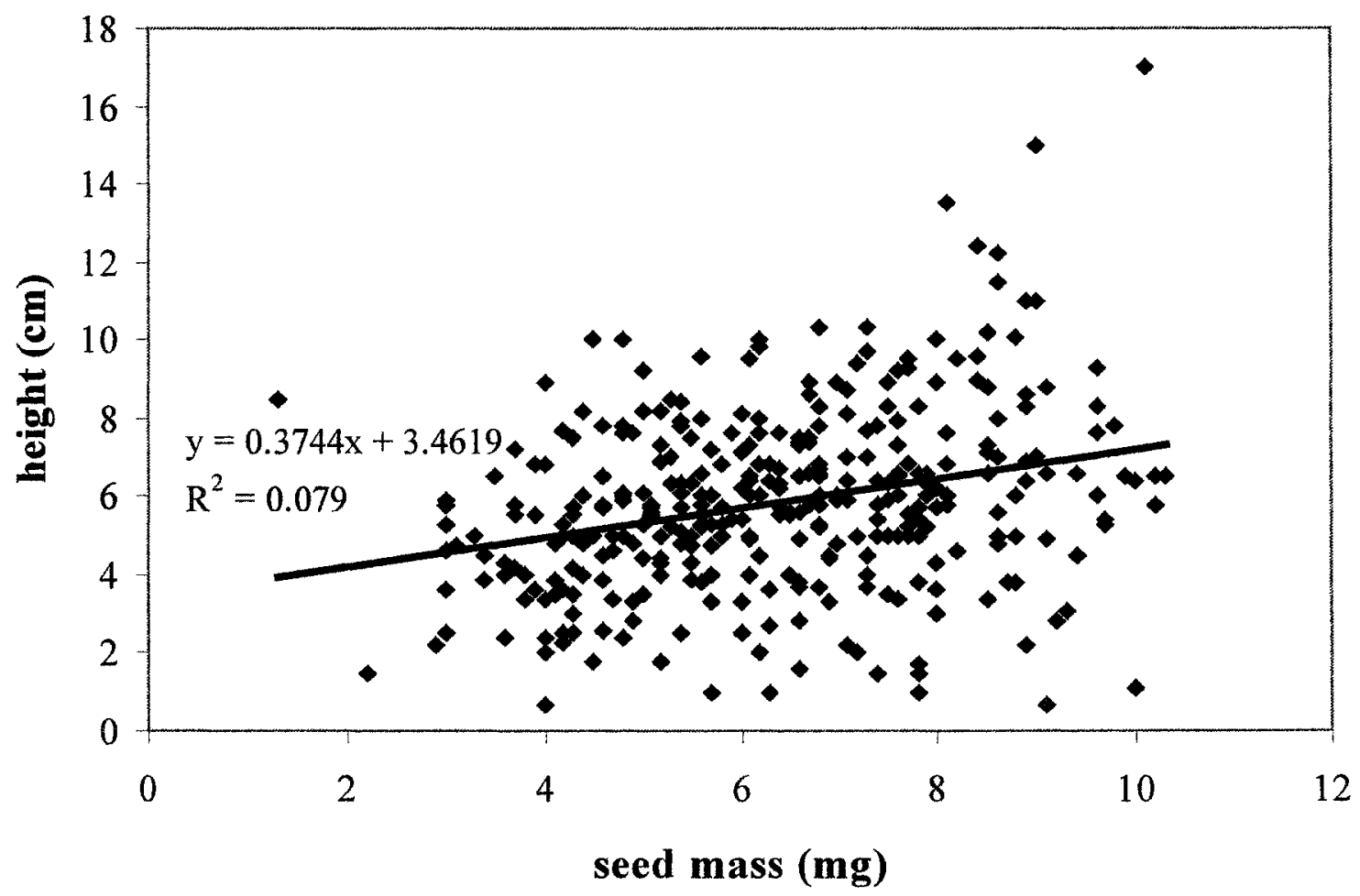

Figure 9. Maximum total height attained by $V$. rossicum seedlings from below-ground plantings in the first season predicted by seed mass. 


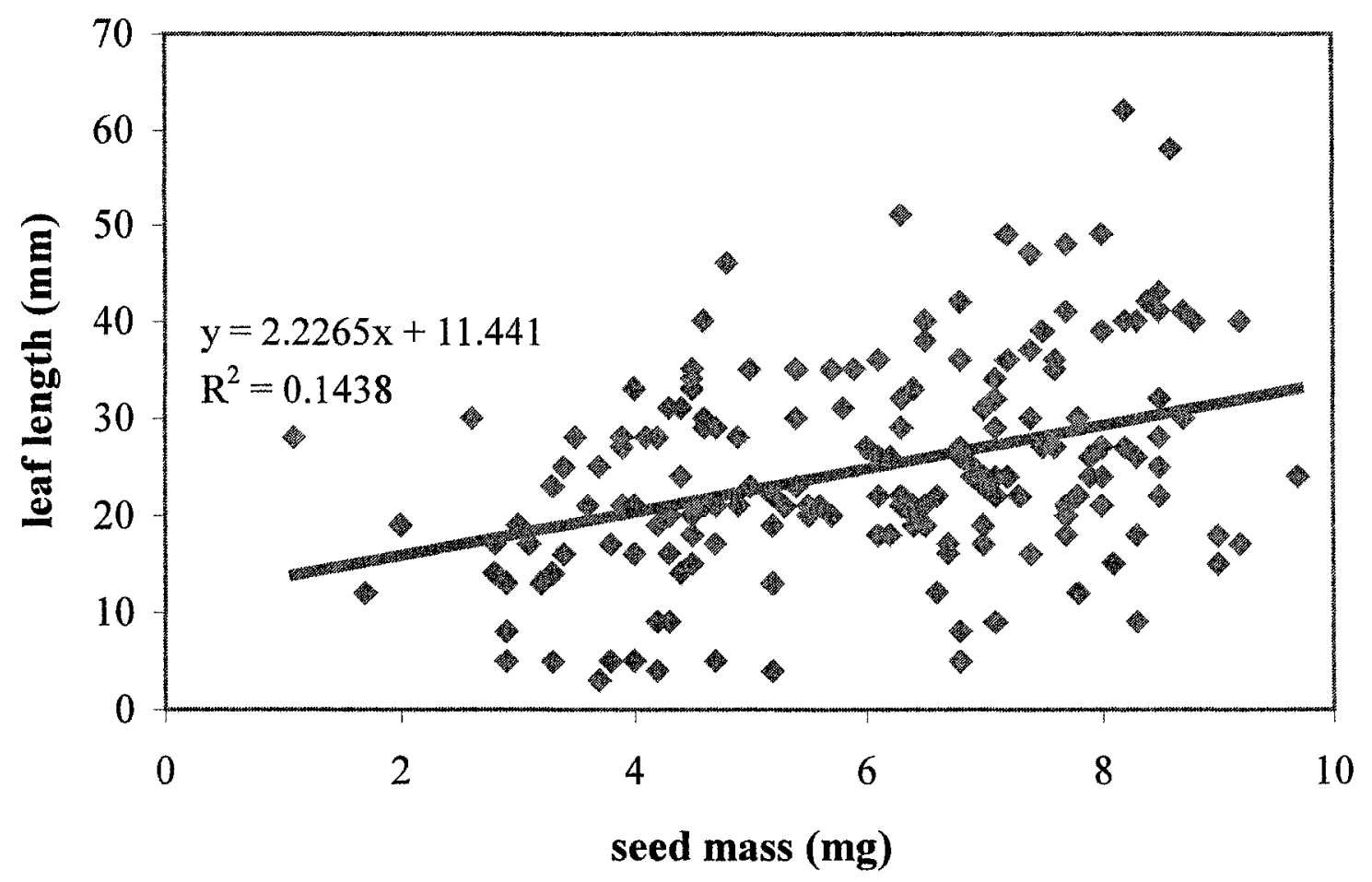

Figure 10. Maximum total leaf length of $V$. rossicum seedlings in season 1 predicted by seed mass in the above-ground planting experiment.

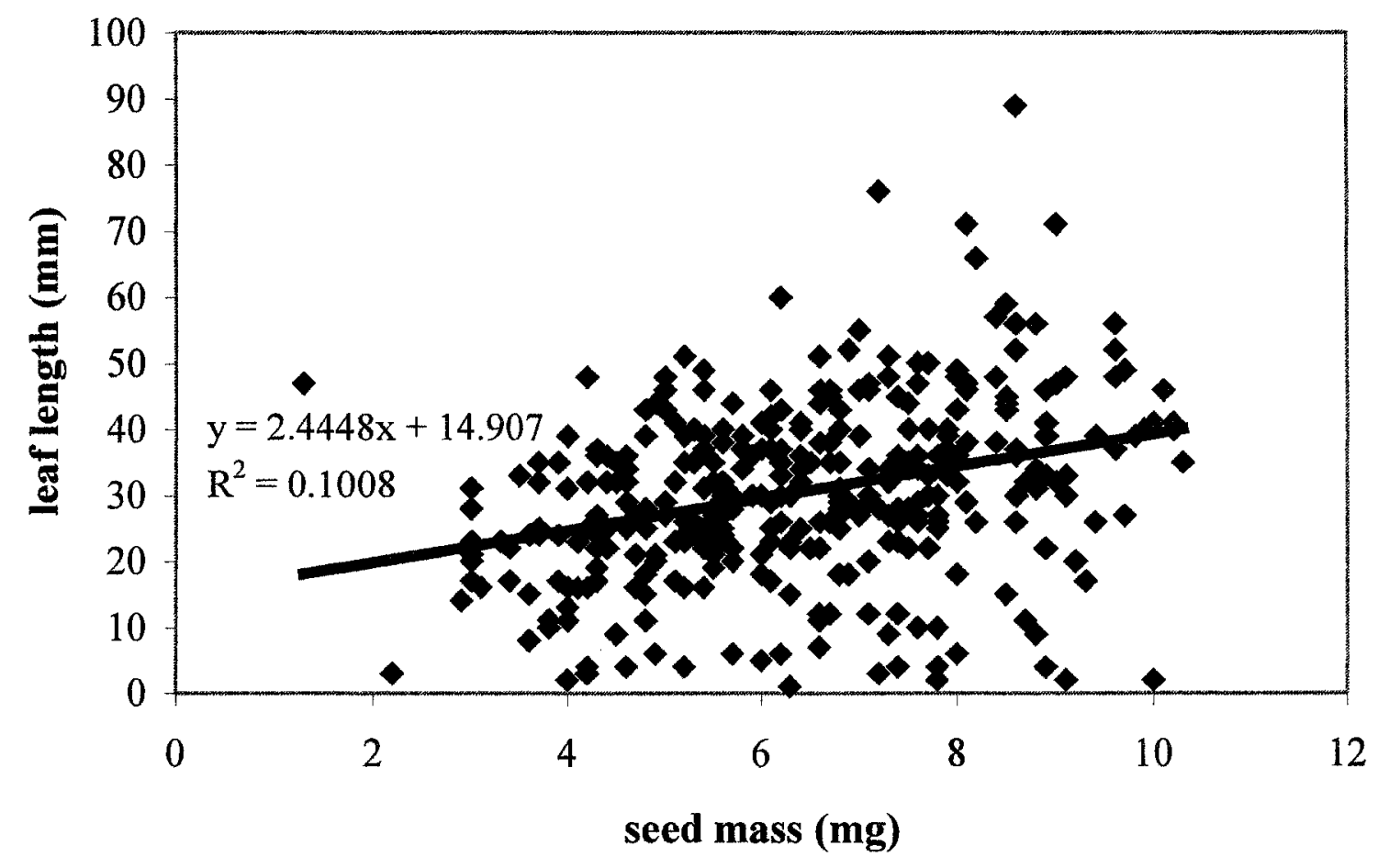

Figure 11. Maximum total leaf length of $V$.rossicum seedlings in season 1 predicted by seed mass in the below-ground planting experiment. 


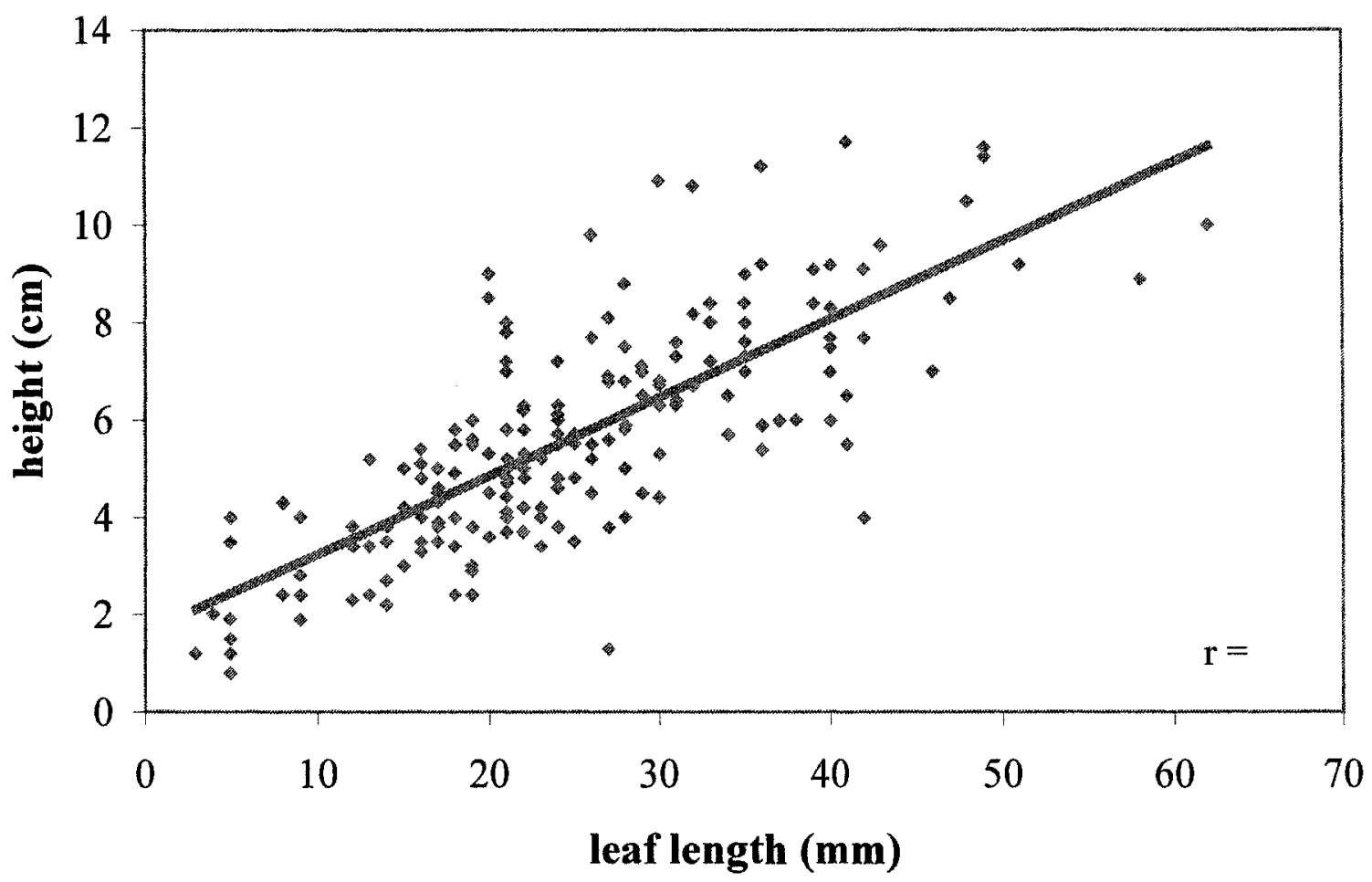

Figure 12. $V$. rossicum seedling height and leaf length in season 1 were correlated in the above-ground planting experiment. Pearson's $r$.

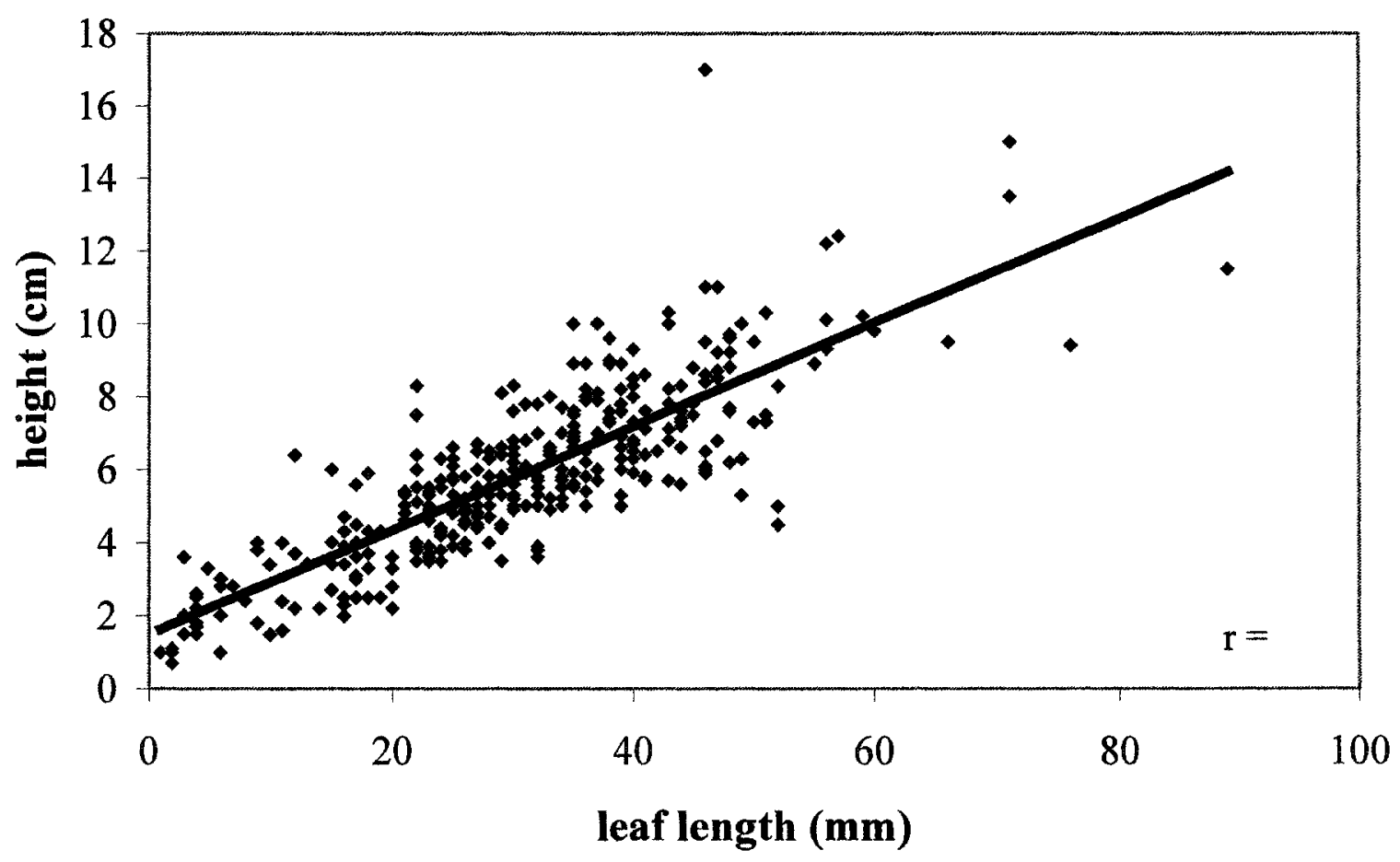

Figure 13. $V$. rossicum seedling height and leaf length in season 1 were correlated in the below-ground planting experiment. Pearson's $r$. 


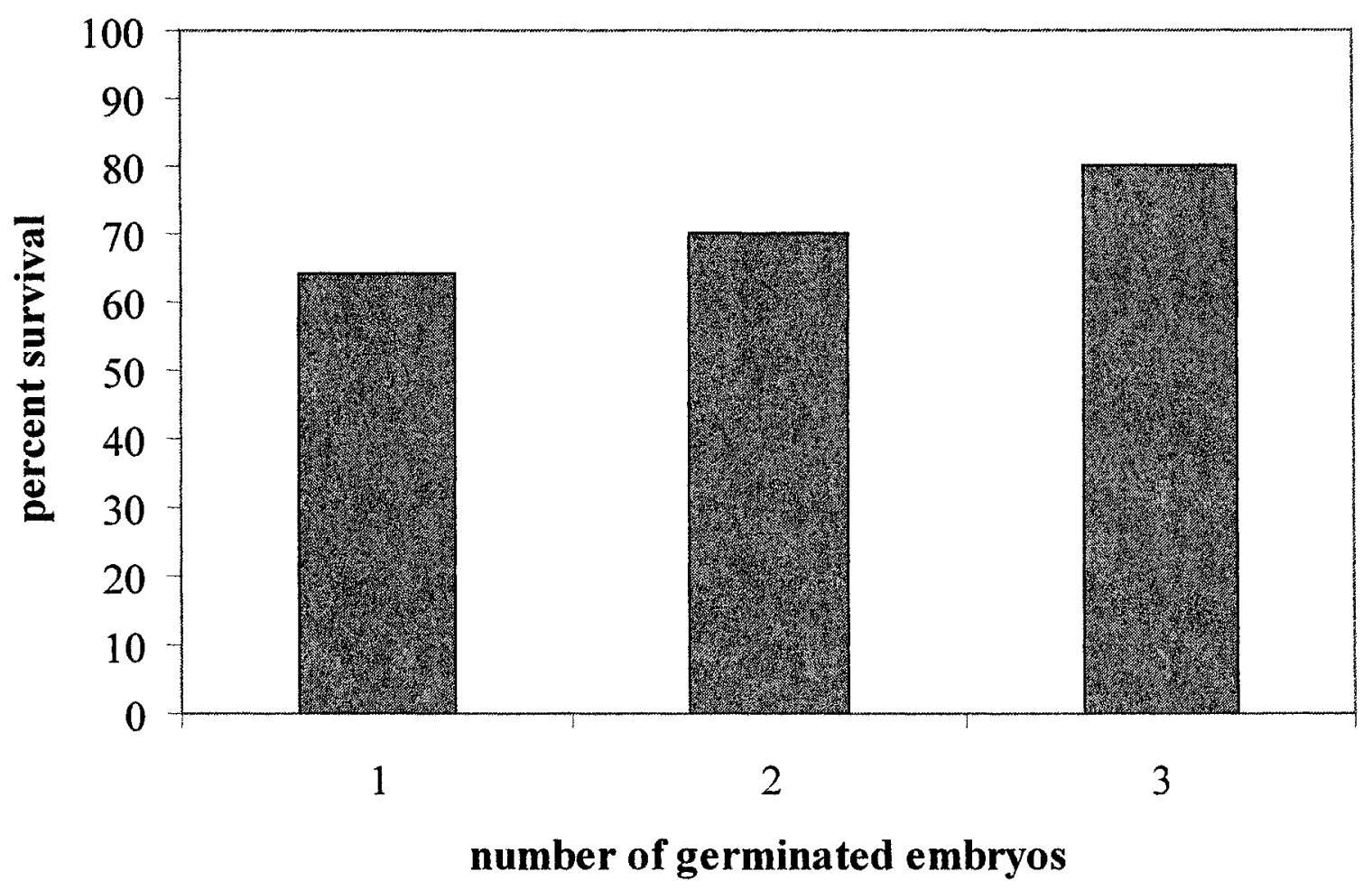

Figure 14. Percentage over-winter survival of $V$. rossicum embryony classes in the above-ground planting experiment.

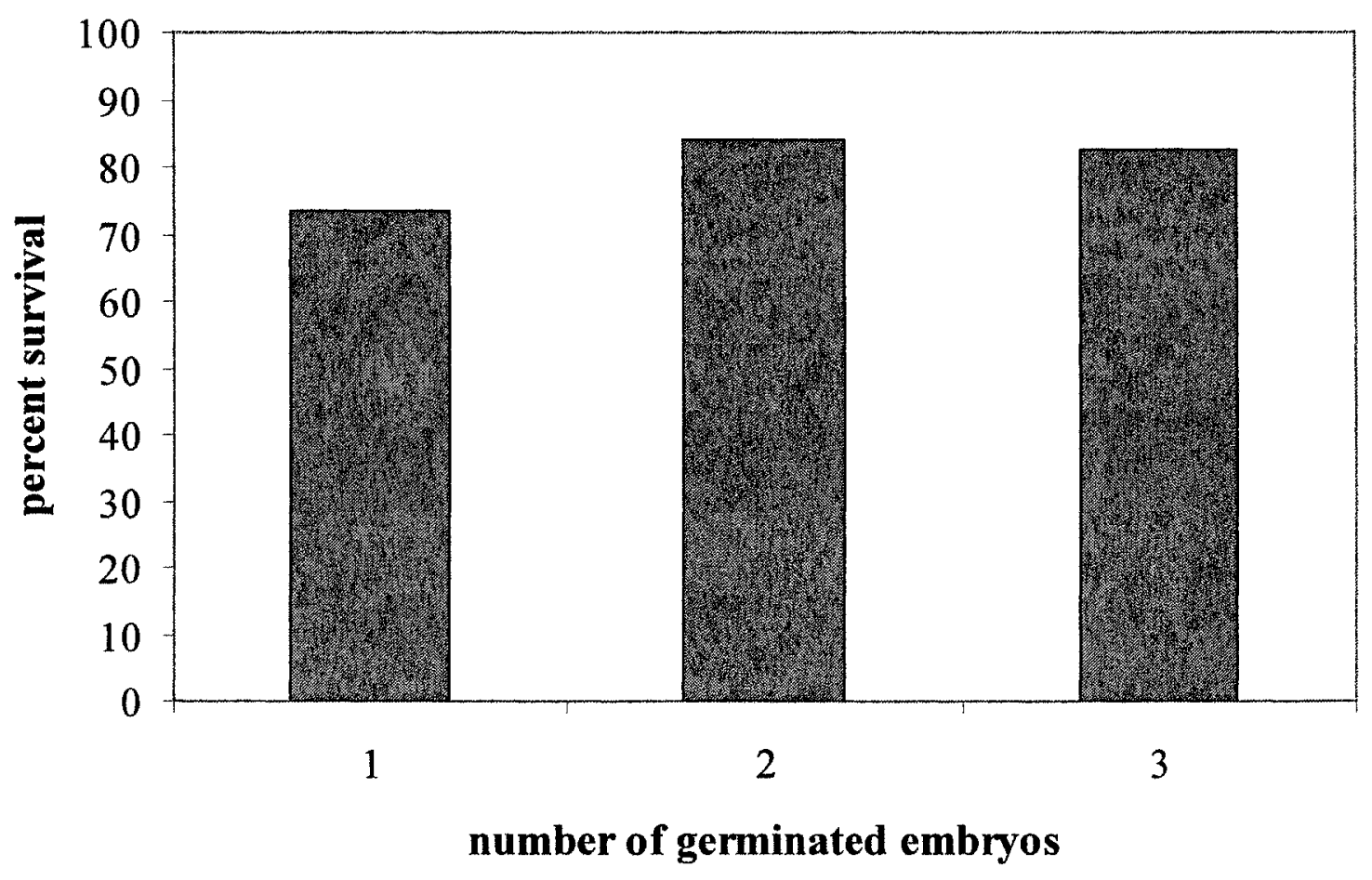

Figure 15. Percentage over-winter survival of $V$.rossicum embryony classes in the below-ground planting experiment. 


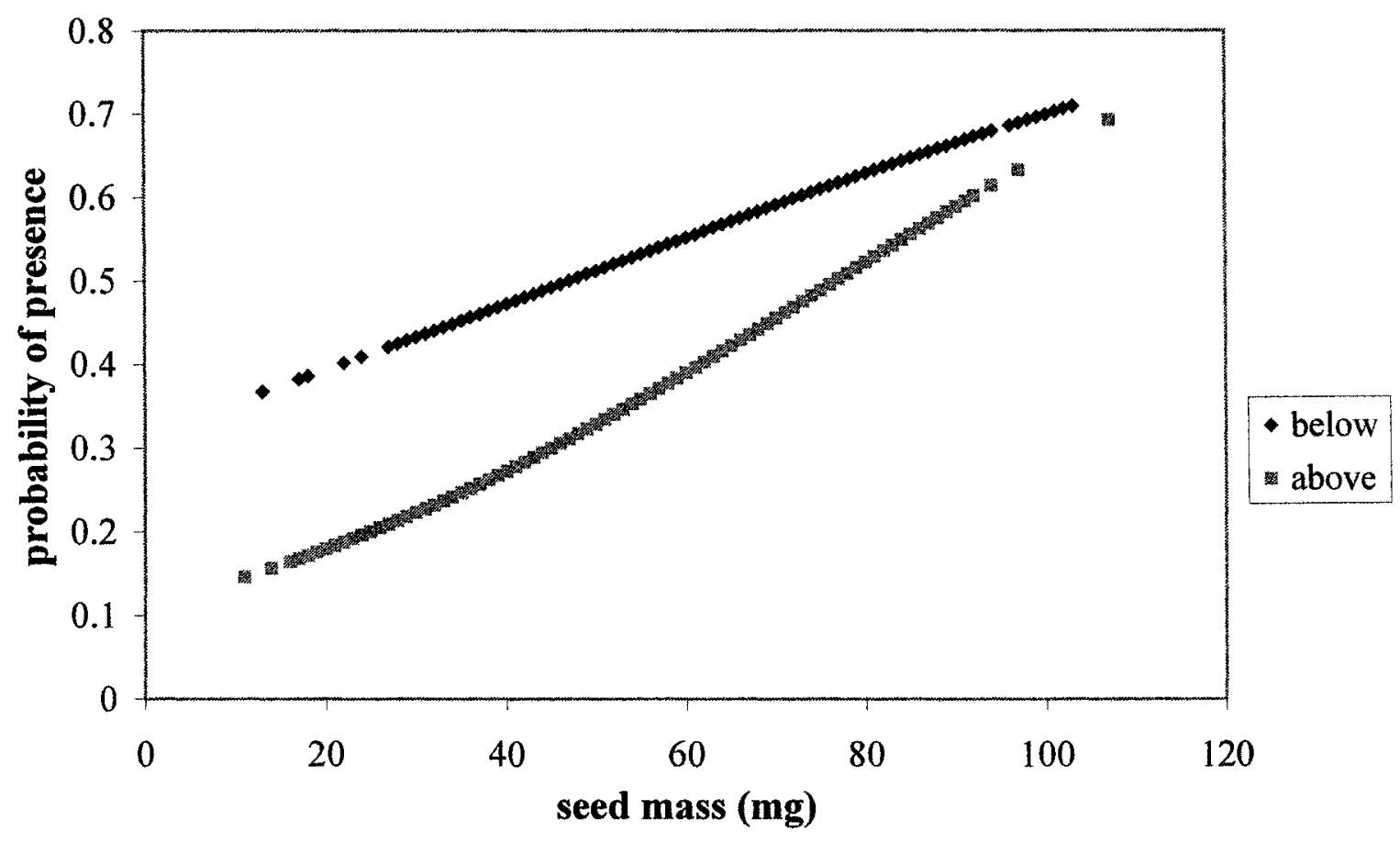

Figure 16. Logistic regression of the probability of seedling presence in the second growing season on initial seed mass in $V$. rossicum above- and below-ground planting experiments. 


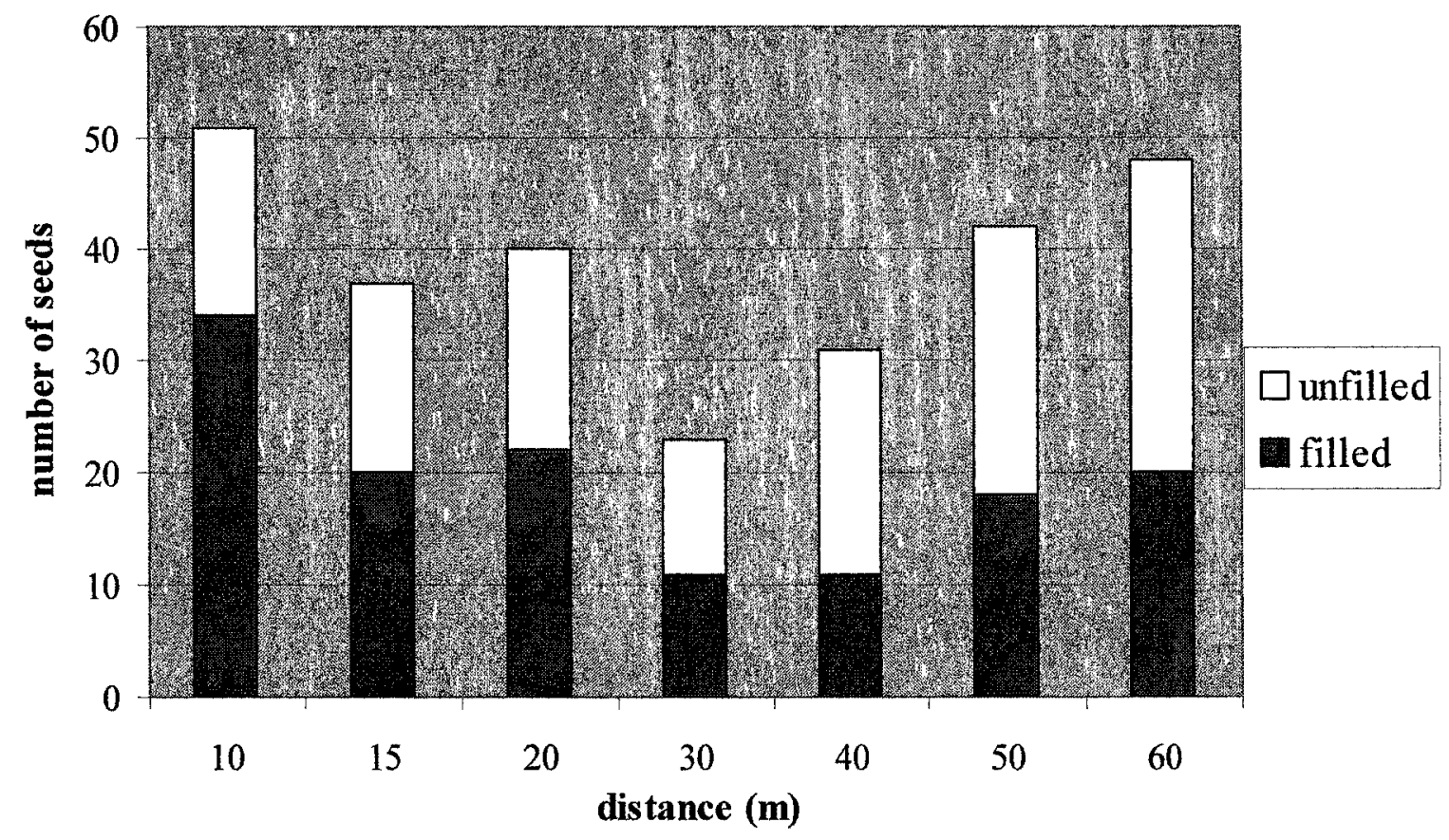

Figure 17. Numbers of filled and unfilled $V$. rossicum seeds dispersed to distances from source.

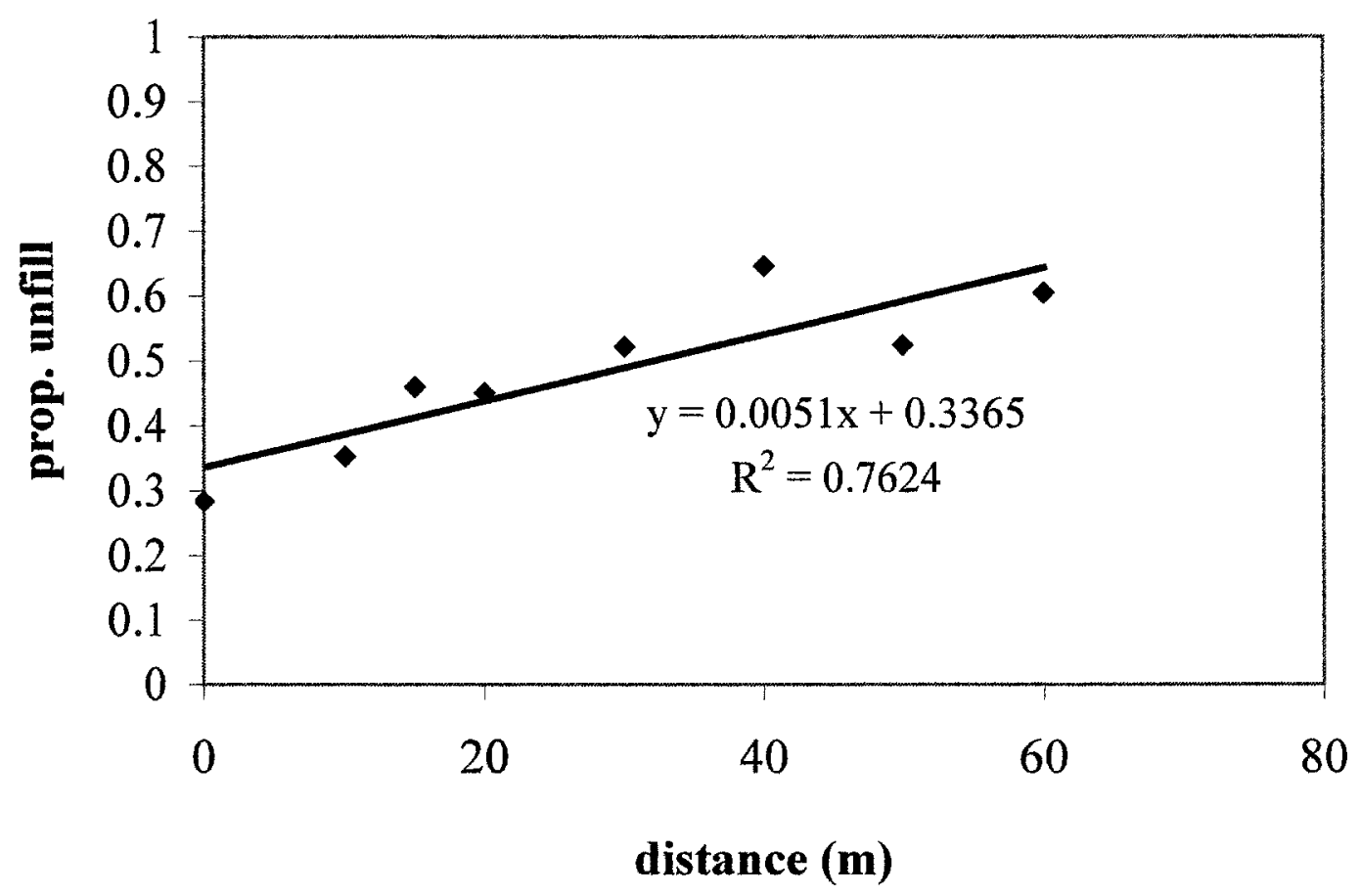

Figure 18. Linear regression of arcsine transformed proportion unfilled $V$. rossicum seeds trapped and their dispersal distance. 


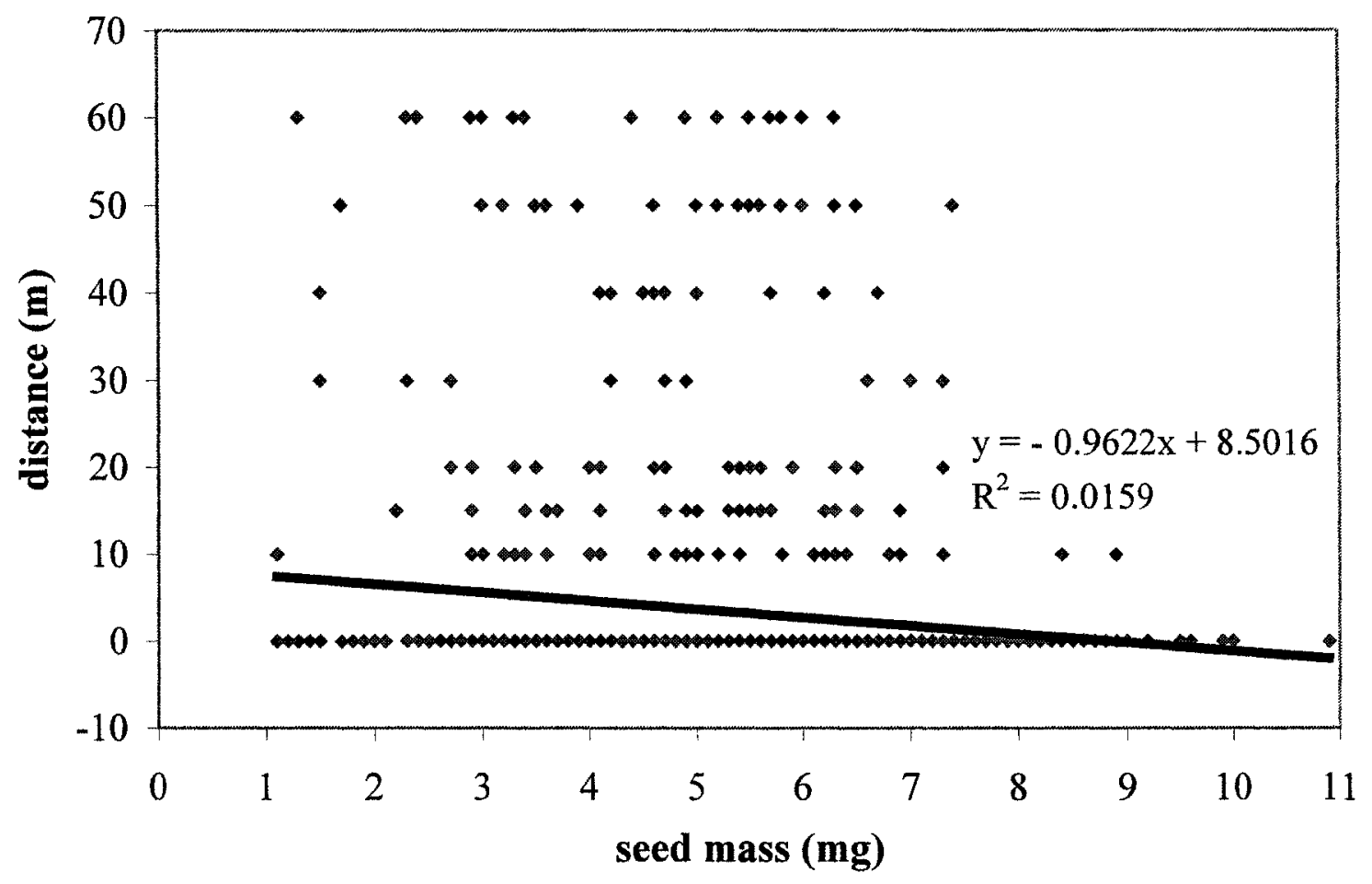

Figure 19. Linear regression of $V$. rossicum seed dispersal distance as a function of mass.

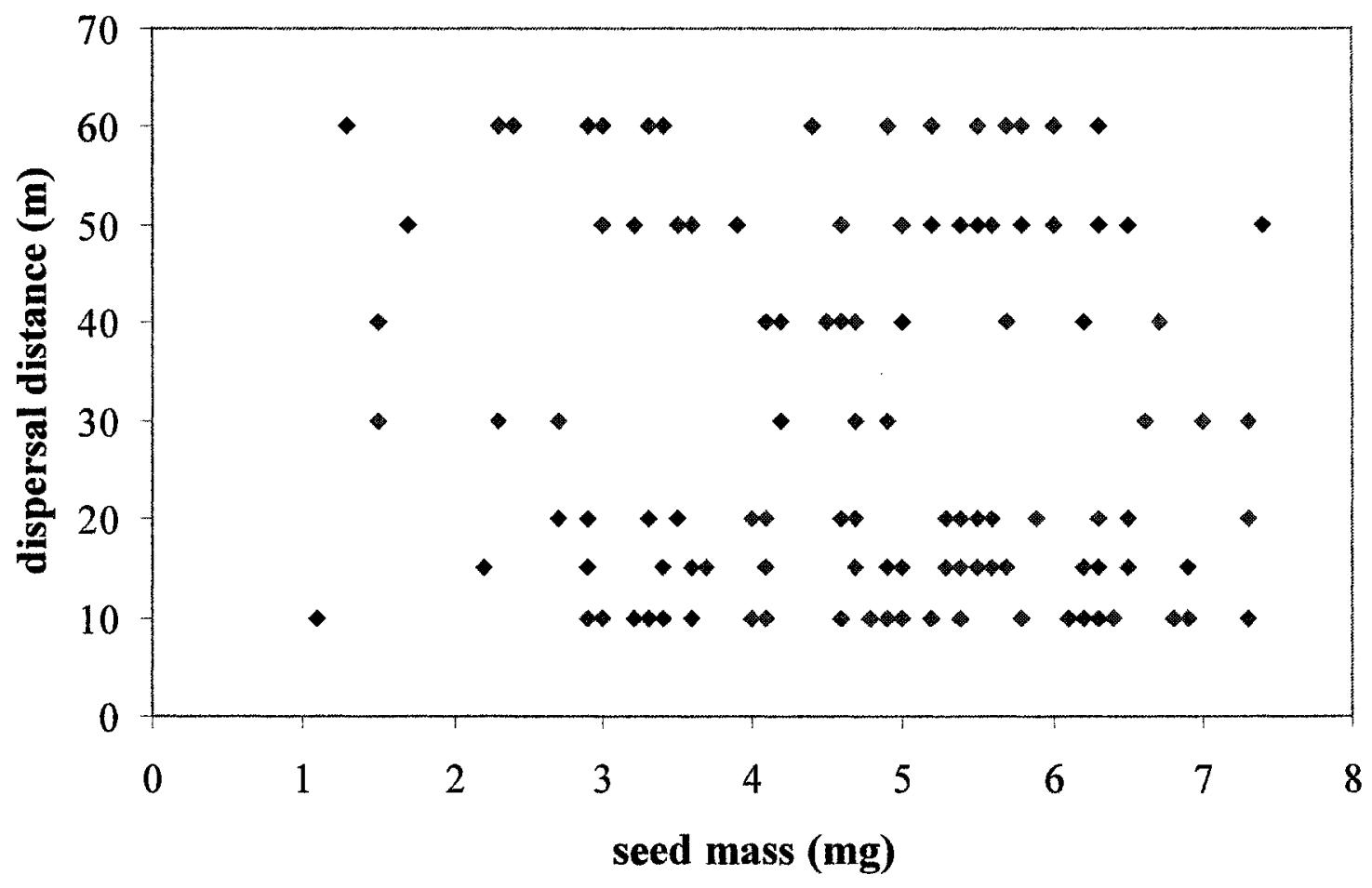

Figure 20. Linear regression of $V$. rossicum dispersal beyond $0 \mathrm{~m}$ as a function of seed mass is not significant when two outliers removed. 


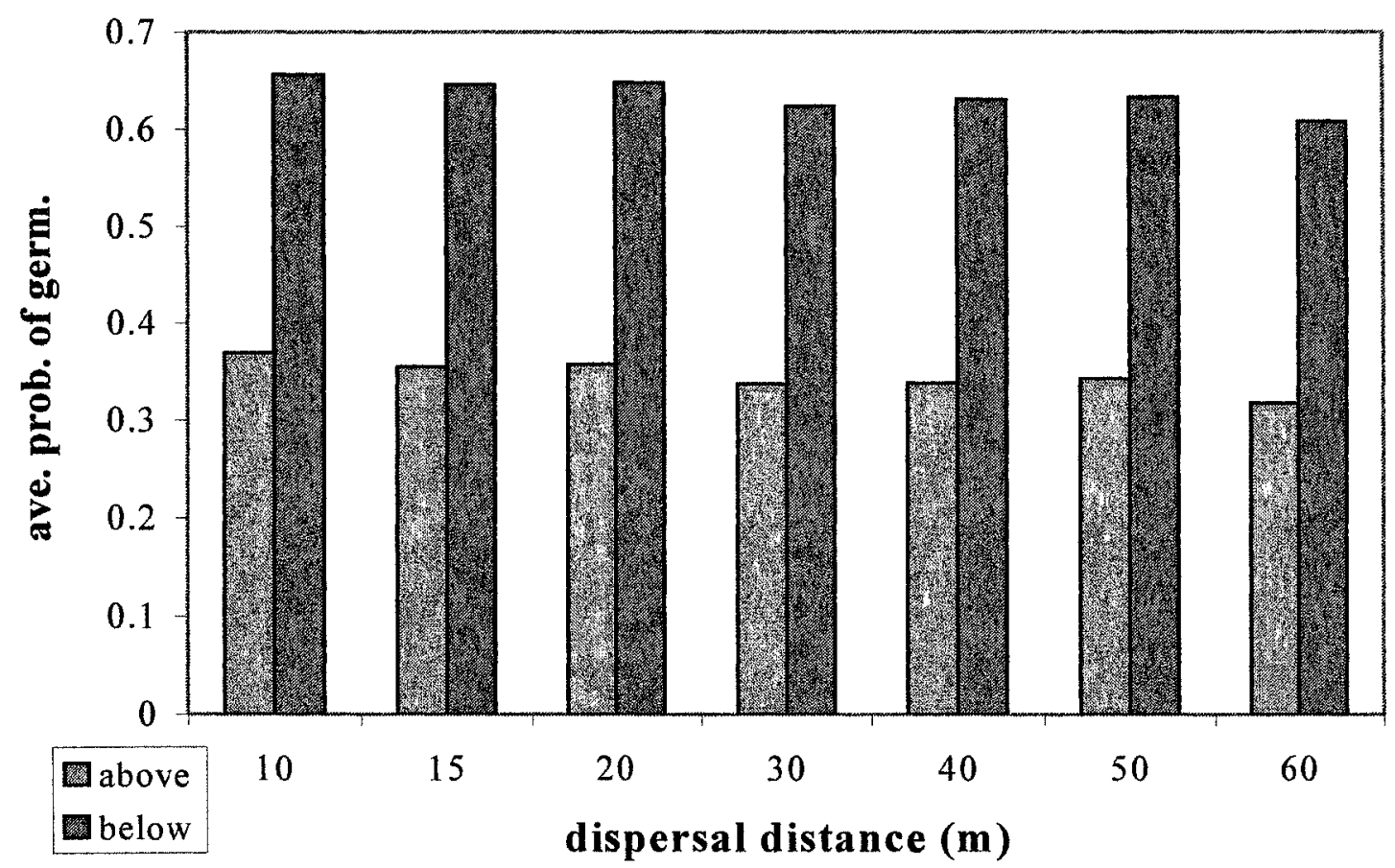

Figure 21. Estimated effective dispersal of $V$. rossicum or probability of germination at each distance. Values based on both planting experiments are shown.

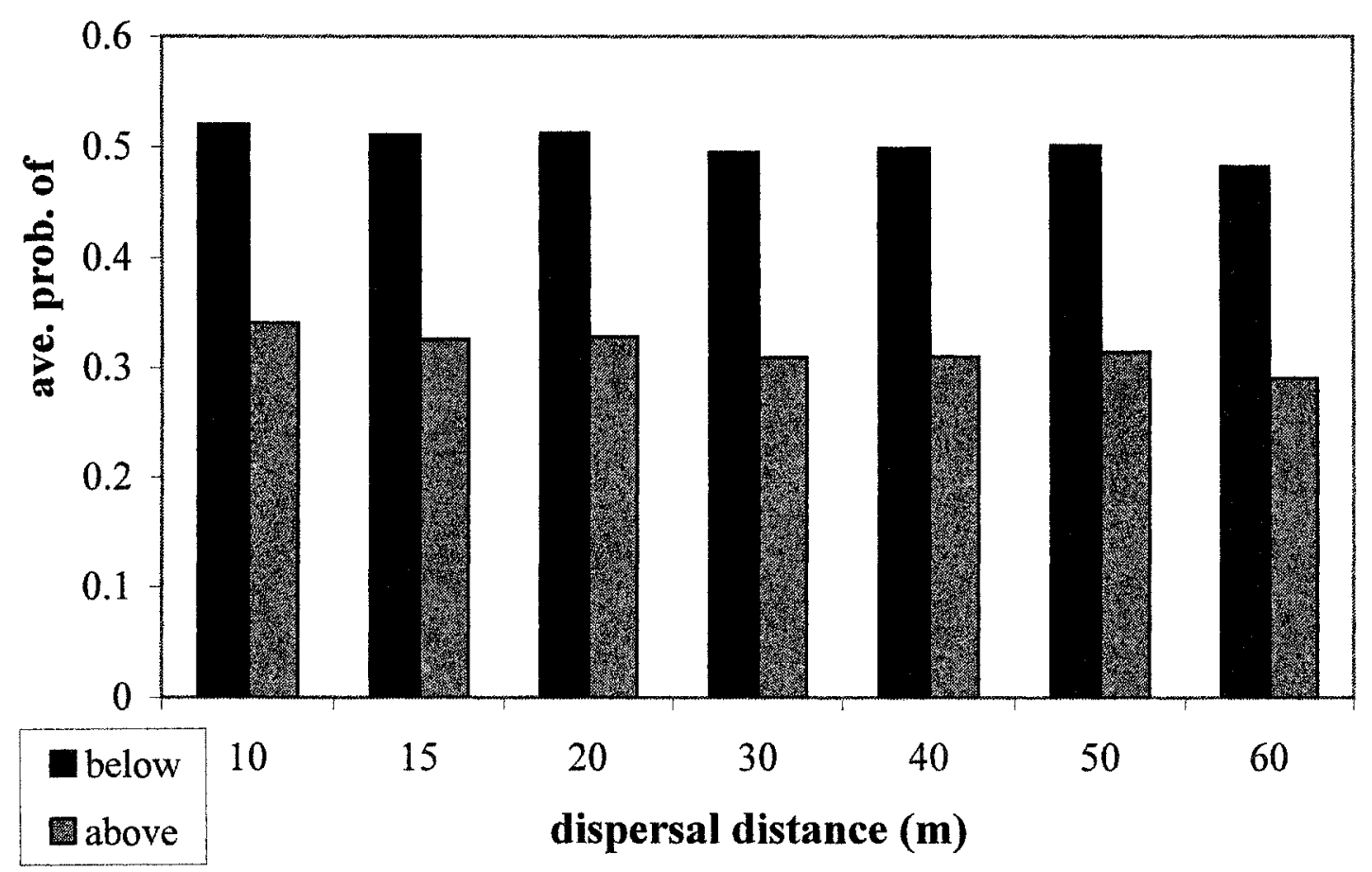

Figure 22. Estimated effective dispersal of $V$. rossicum or probability of seedling presence in the second season at each dispersal distance. Values based on both planting experiments are shown. 